\title{
Mean Conditions and Seasonality of the West Greenland Boundary Current System near Cape Farewell
}

\author{
Astrid PACini, ${ }^{\mathrm{a}, \mathrm{b}}$ Robert S. Pickart, ${ }^{\mathrm{b}}$ Frank BAhr, ${ }^{\mathrm{b}}$ DANiel J. Torres, ${ }^{\mathrm{b}}$ Andrée L. RAmSey, ${ }^{\mathrm{b}}$

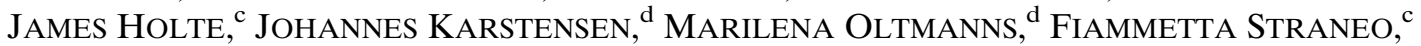 \\ IsABela Astiz Le Bras, ${ }^{\mathrm{c}}$ G. W. K. MOORE, ${ }^{\mathrm{e}}$ AND M. FEMKE DE JONG ${ }^{\mathrm{f}, \mathrm{g}}$ \\ ${ }^{a}$ MIT-WHOI Joint Program in Physical Oceanography, Woods Hole, Massachusetts \\ ${ }^{\mathrm{b}}$ Woods Hole Oceanographic Institution, Woods Hole, Massachusetts \\ ${ }^{\mathrm{c}}$ Scripps Institution of Oceanography, University of California, San Diego, La Jolla, California \\ ${ }^{\mathrm{d}}$ GEOMAR Helmholtz Centre for Ocean Research, Kiel, Germany \\ ${ }^{\mathrm{e}}$ Department of Physics, University of Toronto, Toronto, Ontario, Canada \\ ${ }^{\mathrm{f}}$ NIOZ Royal Netherlands Institute for Sea Research, Texel, Netherlands \\ ${ }^{\mathrm{g}}$ Utrecht University, Texel, Netherlands
}

(Manuscript received 23 April 2020, in final form 1 July 2020)

\begin{abstract}
The structure, transport, and seasonal variability of the West Greenland boundary current system near Cape Farewell are investigated using a high-resolution mooring array deployed from 2014 to 2018. The boundary current system is comprised of three components: the West Greenland Coastal Current, which advects cold and fresh Upper Polar Water (UPW); the West Greenland Current, which transports warm and salty Irminger Water (IW) along the upper slope and UPW at the surface; and the Deep Western Boundary Current, which advects dense overflow waters. Labrador Sea Water (LSW) is prevalent at the seaward side of the array within an offshore recirculation gyre and at the base of the West Greenland Current. The 4-yr mean transport of the full boundary current system is $31.1 \pm 7.4 \mathrm{~Sv}\left(1 \mathrm{~Sv} \equiv 10^{6} \mathrm{~m}^{3} \mathrm{~s}^{-1}\right)$, with no clear seasonal signal. However, the individual water mass components exhibit seasonal cycles in hydrographic properties and transport. LSW penetrates the boundary current locally, through entrainment/mixing from the adjacent recirculation gyre, and also enters the current upstream in the Irminger Sea. IW is modified through air-sea interaction during winter along the length of its trajectory around the Irminger Sea, which converts some of the water to LSW. This, together with the seasonal increase in LSW entering the current, results in an anticorrelation in transport between these two water masses. The seasonality in UPW transport can be explained by remote wind forcing and subsequent adjustment via coastal trapped waves. Our results provide the first quantitatively robust observational description of the boundary current in the eastern Labrador Sea.
\end{abstract}

\section{Introduction}

Convection at high latitudes in the North Atlantic produces intermediate and overflow waters (Dickson and Brown 1994; Lazier et al. 2002) and is responsible for the downwelling branch of the global overturning circulation (e.g., Killworth 1983; Våge et al. 2008). The resulting meridional flux of heat helps regulate Northern Hemisphere climate. Furthermore, the convection is an important mechanism for carbon sequestration from the atmosphere to the deep ocean (Takahashi et al. 2009; Khatiwala et al. 2013). Due in part to the small Rossby radius of deformation at high latitudes, more extensive

Corresponding author: Astrid Pacini, apacini@whoi.edu observations are needed to quantify the extent to which the regional current systems contribute to these processes.

There are two locations where open-ocean convection forms the intermediate water mass known as Labrador Seawater (LSW): the western Labrador Sea (Clarke and Gascard 1983; Lab Sea Group 1998; Pickart et al. 2002) and the southwestern Irminger Sea (Pickart et al. 2003a,b). The strength of convection, due to large heat fluxes and wind stress curl, varies greatly from year to year and is intimately connected with the North Atlantic Oscillation and the associated westerly winds (Hurrell 1995; Våge et al. 2009). The mechanisms that govern convection in the two basins differ. Convection in the Labrador Sea is predominately driven by passing low 
pressure systems that draw cold air off of the Labrador landmass and increase the surface heat loss from the ocean, in conjunction with changes in ice cover (Våge et al. 2009). Convection in the Irminger Sea is more tightly coupled to the presence of the forward Greenland tip jet, a localized, narrow atmospheric jet that results from the interaction of passing atmospheric cyclones with the high topography of southern Greenland. These features act to enhance surface buoyancy loss and produce LSW (e.g., Pickart et al. 2003a; Våge et al. 2008).

The newly ventilated intermediate waters are exported from the subpolar gyre by way of the boundary current system of the Irminger and Labrador Seas (Pickart 1992; Dickson and Brown 1994; Fischer et al. 2010) and also via interior pathways (Lavender et al. 2000; Bower et al. 2009). In the Irminger Sea, the boundary current system consists of the following components, progressing from onshore to offshore: the East Greenland Coastal Current (EGCC) (Bacon et al. 2002; Sutherland and Pickart 2008); the East Greenland/Irminger Current (EGC/IC) in the vicinity of the shelfbreak (Sutherland and Pickart 2008); the East Greenland Spill Jet on the upper continental slope (e.g., von Appen et al. 2014b); and finally the Deep Western Boundary Current (DWBC) at the base of the slope (Dickson and Brown 1994) (Fig. 1). The EGCC transports Arctic-origin water and glacial runoff from Greenland between the surface and $200 \mathrm{~m}$ (Bacon et al. 2002; Sutherland and Pickart 2008). The EGC/IC advects a combination of Arctic waters exported through Denmark Strait and Atlantic-origin waters from the Irminger Sea (Cuny et al. 2002; Pickart et al. 2005; Fratantoni and Pickart 2007). The East Greenland Spill Jet is believed to combine with the EGC/IC as the two currents flow southward toward Cape Farewell (Brearley et al. 2012; von Appen et al. 2014b). The DWBC advects overflow waters that are ventilated in the Nordic Seas (Dickson and Brown 1994).

The EGCC, EGC/IC, and DWBC from the eastern side of Greenland persist around the southern tip of Greenland, known as Cape Farewell, to form the West Greenland boundary current system (see Fig. 1b). Northwest of Cape Farewell, the EGCC becomes the West Greenland Coastal Current (WGCC), and the EGC/IC becomes the West Greenland Current (WGC). While previous studies have considered the WGCC and WGC as a single flow (e.g., Rykova et al. 2015), here we distinguish the two components based on their water mass characteristics. It has recently been shown that, as the coastal current rounds Cape Farewell, it gets diverted close to the shelfbreak due to the local bathymetry. This allows some of the freshwater advected by the current to be fluxed seaward into the basin via baroclinic instability (Lin et al. 2018). Additionally, Holliday et al. $(2007,2009)$ argue that approximately one-third of both the EGC/IC transport and DWBC transport recirculate into the Irminger Sea at Eirik Ridge, the seaward protrusion of the 2000-3500-m bathymetric contours south of Cape Farewell.

Progressing northward, some portion of the WGCC and WGC flows through Davis Strait into Baffin Bay (Cuny et al. 2005; Curry et al. 2011, 2014), while the remainder circulates around the northern edge of the Labrador Sea and turns southward along the Labrador and Newfoundland coasts. In addition to advecting water masses equatorward via the mean flow, strong mesoscale variability (e.g., Lilly et al. 1999) and Ekman transport play important roles in the exchange of waters between the boundary current and the interior Labrador Sea (Luo et al. 2016; Schulze Chretien and FrajkaWilliams 2018). This is vital for modulating the convective overturning during winter, restratifying the interior during spring (e.g., Straneo 2006), and fluxing the newly ventilated LSW to lower latitudes (e.g., Le Bras et al. 2017).

Unlike the western Irminger Sea and the western Labrador Sea, the boundary current system in the eastern Labrador Sea has not been well studied. The observations to date have consisted of limited shipboard sections, taken mostly during the warm months of the year. Repeat occupations of the AR7W line, extending from the Newfoundland shelf to the West Greenland shelf, have been performed annually since 1990 (see Fig. 1b; note that the western end of this line was omitted in some years; see Lazier et al. 2002). In addition, a set of boundary current sections across the West Greenland shelf/slope is carried out each year (Ribergaard 2013). Several studies have used these data, plus a smaller amount of wintertime shipboard sections, to investigate the mean, seasonal, and interannual variability of the WGCC and WGC. Rykova et al. (2015), using 18 occupations of the AR7W line (5 in wintertime) and altimeter-derived surface velocity, concluded that the WGCC exhibits a maximum in transport in the summer months (May-July), while the Atlantic-origin water in the WGC exhibits a maximum in temperature, salinity, and transport in the winter months (October-February). Using a diagnostic model for barotropic velocities together with the West Greenland sections, Myers et al. (2007) showed that the Atlantic-origin water is highly variable on interannual time scales in volume transport, lateral position, and salinity signature, with maxima in temperature, salinity, and transport in the 1960s. Using a similar approach, Myers et al. (2009) investigated the interannual variability of the presence of low-salinity waters on the shelf. 

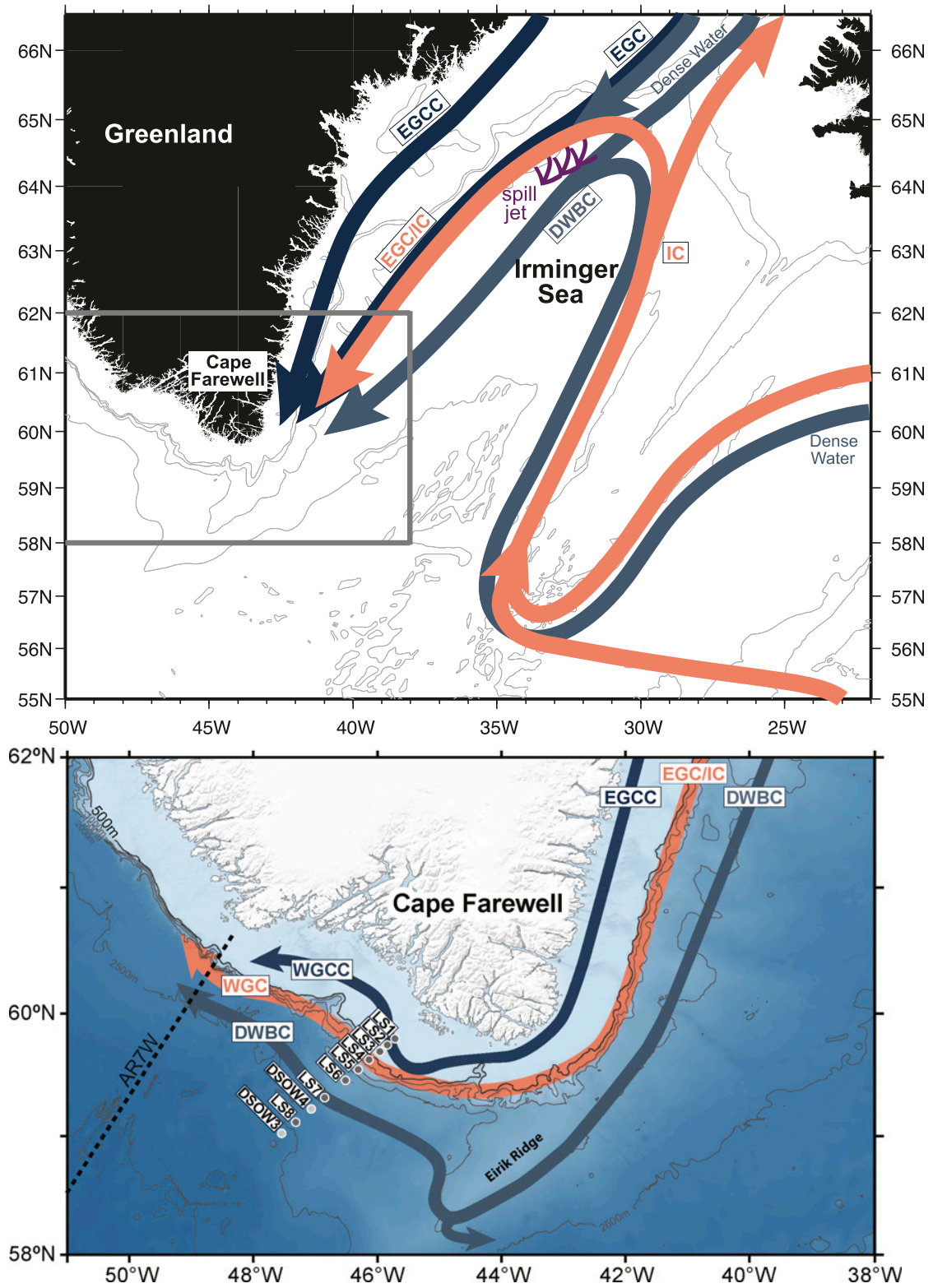

FIG. 1. (a) Schematic circulation around the Irminger Sea and in the East Greenland boundary current system. See (b) for enlarged view within the gray box. (b) Schematic circulation around the southern tip of Greenland, with the OSNAP West Greenland moorings marked by the gray circles. Dark gray indicates full-depth moorings, and light gray indicates bottom-instrumented moorings. The black dashed line indicates the AR7W hydrographic line.

A region of high eddy kinetic energy on the West Greenland slope has been observed from satellite data and Lagrangian profilers (e.g., Prater 2002; Lilly et al. 2003). Anticyclonic features called Irminger Rings, with a core of warm, saline Atlantic-origin water, are spawned from this location and travel southwestward across the Labrador Sea, before spinning down in the interior of the basin (Lilly et al. 1999; Prater 2002; Rykova et al. 2009; de Jong et al. 2014). Modeling studies have addressed the role of the boundary current, and this hot spot in particular, in fluxing properties into the interior Labrador Sea. It has been determined that the Irminger Rings, together with convective eddies (spawned by convection within the Labrador Sea) and boundary current eddies (spawned by instabilities all along the WGC), help balance the wintertime heat loss in the interior Labrador Sea (e.g., Gelderloos et al. 2011). 
While the studies to date have advanced our understanding of the boundary current system west of Greenland, the observational description is largely incomplete. This is in part due to the lack of mooring time series, which provide information throughout the seasonal cycle. Here we present results from the first high-resolution mooring array deployed across the West Greenland boundary current system. The array is maintained as part of the Overturning in the Subpolar North Atlantic Program (OSNAP) (Lozier et al. 2017). We report on the first four years of data, 2014-18, and quantify the mean conditions and seasonality of the component water masses and velocity cores comprising the boundary current system. We further explain the nature of the seasonal signals and their connection to upstream conditions. The structure of the paper is as follows. In section 2 the data and processing are reported; the mean conditions are described in section $3 \mathrm{a}$; the water masses are identified in section $3 b$; the transports are quantified in section $3 c$; the seasonality is diagnosed in section $3 \mathrm{~d}$; and a summary and conclusions are presented in section 4 .

\section{Data and methods}

\section{a. West Greenland mooring array}

\section{1) MOORING CONFIGURATION}

The data analyzed in this study come from 10 moorings, referred to as LS1-LS8, DSOW3, and DSOW4 (Fig. 1b), deployed as part of OSNAP. This is a sixnation observational program that seeks to measure the time-varying meridional overturning circulation, heat flux, and freshwater flux in the northern North Atlantic, at approximately $60^{\circ} \mathrm{N}$. It consists of a suite of platforms, including moorings, gliders, floats, and hydrographic surveys (Lozier et al. 2017, 2019). The West Greenland mooring array presented here is referred to as the OSNAP WG array.

The configuration of the OSNAP WG array in the vertical is shown in Fig. 2. Moorings LS1-LS3 on the West Greenland shelf are tripods that sit on the seafloor and contain an upward-facing acoustic Doppler current profiler (ADCP) and a MicroCAT measuring temperature, conductivity, and pressure. A second MicroCAT was situated on a buoyant tether at $50 \mathrm{~m}$ and connected to the tripod with a weak link. The link was designed to break free in case of an encounter with an iceberg. Moorings LS4-LS8 are tall moorings with top floats situated at $100 \mathrm{~m}$ containing an ADCP and MicroCAT. Beneath this were pairs of MicroCATs and Aquadopps spaced every $250-500 \mathrm{~m}$. The Aquadopps provide point measurements of velocity. Each of the tall moorings contained a weak-link tether $50 \mathrm{~m}$ above the top float

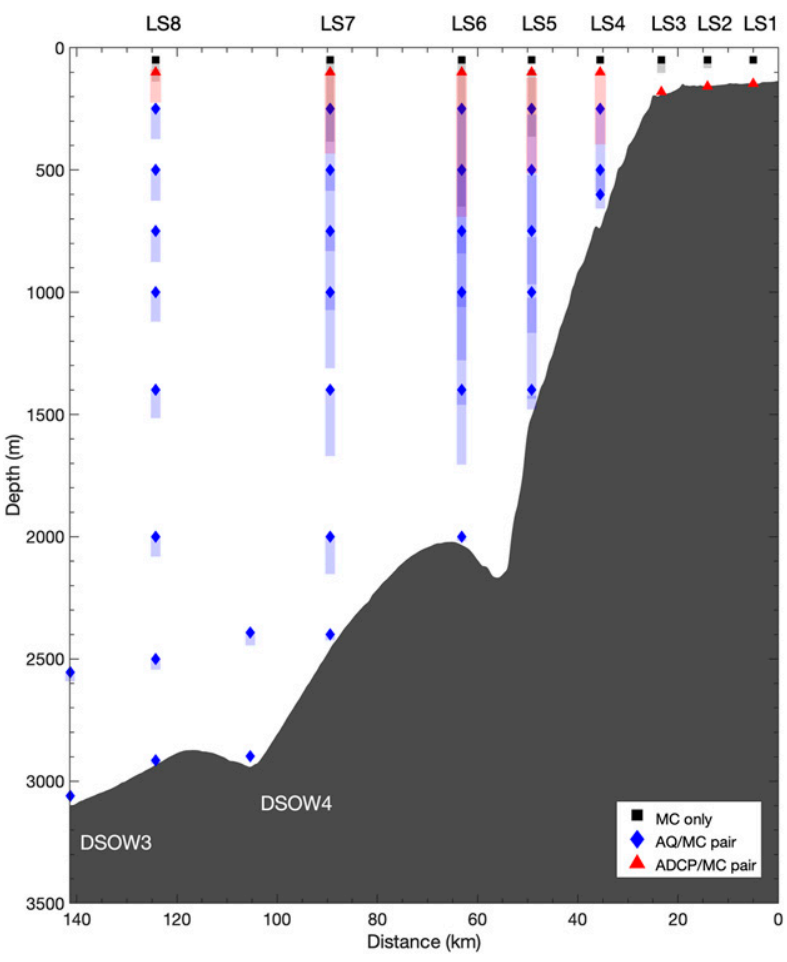

FIG. 2. OSNAP WG instrument configuration (see the legend). The eight LS moorings were deployed by the Woods Hole Oceanographic Institution, and the two DSOW moorings were deployed by GEOMAR, Helmholtz Centre for Ocean Research, Kiel. Shading indicates the maximum vertical displacement of the instrumentation due to mooring blow downs.

with a MicroCAT. The final two moorings, DSOW3 and DSOW4, are short bottom moorings with AquadoppMicroCAT pairs extending to $500 \mathrm{~m}$ above the bottom. The total instrumentation consisted of 49 MicroCATs, 33 Aquadopps, and 8 ADCPs (the ADCPs recorded temperature as well).

The overall data return over the 4-yr period was $86 \%$. Separated by instrument type, it was $80.7 \%$ for MicroCAT temperature, $80.8 \%$ for MicroCAT salinity, $99.8 \%$ for the Aquadopps, and $99.6 \%$ for the ADCPs. The largest data loss was associated with the tethered MicroCATs. A significant number of these were torn off (presumably by icebergs), although in some cases the MicroCAT flotation was destroyed and the instrument settled at a deeper depth. Excluding the tethered MicroCATs, the overall data return was $91.9 \%$. The 2014-16 hydrographic time series from the 50-m MicroCAT at LS6 and the bottom MicroCAT at LS4 were removed because of the presence of sharp salinity jumps, possibly due to biofouling. Moorings LS4-LS7 experienced regular blowdowns due to unexpectedly strong currents (Fig. 2). This was most pronounced at LS6, where, on occasion, some of the instruments were drawn down as much as $600 \mathrm{~m}$ in the 
vertical. Note that this is not generally a data loss, just a redistribution of the vertical coverage during energetic events. The details of this are described in section $2 \mathrm{a}(2)$. All of the data were subsampled to hourly resolution, in order to match the sampling frequency of the ADCPs (the lowest common denominator for sampling frequency).

\section{2) DATA PROCESSING}

\section{(i) MicroCATs}

Temperature, conductivity, and pressure were measured every $15 \mathrm{~min}$ using SBE37 MicroCATs. The initial MicroCAT precision is $\pm 0.002^{\circ} \mathrm{C}$ and $\pm 0.0003 \mathrm{~S} \mathrm{~m}^{-1}$ for temperature and conductivity, respectively. This means the instruments provide a precision of $\pm 0.0001-0.005$ in salinity given a temperature range of $0^{\circ}-8^{\circ} \mathrm{C}$. The conductivity measurements tend to drift over the course of a deployment. Shipboard conductivity-temperature-depth (CTD) casts were used to calibrate the instruments, following the methods outlined by Kanzow et al. (2006). The MicroCATs were attached to the CTD rosette and lowered to predetermined depths, then held at these positions for $10 \mathrm{~min}$. This was done both before the instruments were deployed and then immediately upon recovery. These pre- and postdeployment calibration casts were then used to remove the drift (assumed to be linear) associated with the instrument during the 2-yr deployment.

\section{(ii) Aquadopps}

Postdeployment processing of the Aquadopp data included a velocity rotation to correct for the local magnetic declination. The manufacturer's quality flag, based on an instrument tilt threshold, was triggered in cases of significant mooring blowdown due to the anomalously strong velocities. However, when inspecting the full Aquadopp measurement suite, including horizontal and vertical velocity components as well as roll and pitch across neighboring instruments, it was evident that this automatic editing was too restrictive. Furthermore, during the strongest blowdown events, the recorded roll/pitch could actually decrease in an apparent roll-over effect of the tilt sensors; in extreme cases this went below the threshold value. In response, we edited the data based on visual inspection, particularly during the blowdown events, to identify poor returns. This included assessment of excessive roll/pitch and vertical velocity, as well as consideration of outlier horizontal velocities relative to nearby instruments.

\section{(iii) $A D C P s$}

Each OSNAP mooring used either a 75-kHz Teledyne RD Instruments Long Ranger (LR) or a $300-\mathrm{kHz}$
Workhorse (WH) ADCP. Both were processed using MATLAB software routines developed at the Woods Hole Oceanographic Institution. Each hourly ensemble used a sequence of pings (39 pings/ensemble for LR; 60 pings/ensemble for $\mathrm{WH}$ ) that were internally averaged by the instrument. Instrument-derived percent good and error velocity criteria were used to flag bad data. Since all of the ADCPs were upward facing within range of the surface, a side-lobe interference criterion was applied to each record to eliminate bad data near the surface. The top $6 \%$ of the ADCP distance to surface was removed by the side-lobe interference flag. In cases where a MicroCAT was deployed on a tether above the ADCP, the bin where the flotation buoy was located was also corrupted and removed from the final data. A MicroCAT was deployed in combination with each ADCP. The MicroCAT data were interpolated onto the same time grid as the ADCP data and used for depth and speed of sound correction. The depths of each bin were subsequently remapped using the corrected MicroCAT-derived depths. Error criteria thresholds were designed to maximize the amount of good data. Finally, all data were visually inspected and manually corrected for remaining spurious errors not caught by the automated error detection criteria.

\section{3) Detiding AND RotATing VELOCities}

Tidal constituents were computed for the velocity time series using the harmonic tidal routine T_TIDE (Pawlowicz et al. 2002), and the significant constituents were removed. The signal-to-noise ratio (which indicates significance when less than one) is computed by squaring the amplitude divided by its error (computed via bootstrapping). The data were also low-passed with a 36-h Butterworth filter, and the spectral properties of the detided and low-pass-filtered products were compared. They were found to be consistent, which verified successful removal of the semidiurnal (largest constituents: M2, S2) and diurnal (largest constituents: K1, S1, P1) tides. The data used in the remainder of this study are the detided time series.

The detided velocities were subsequently rotated into along-stream and cross-stream components as follows. Using the direction of the mean vectors as an initial choice, the rotation angle was varied at $0.01^{\circ}$ intervals and the mean cross-stream velocity was summed across the array at each value. The angle that minimized this sum (i.e., the cross-stream transport per unit length) was selected as the final rotation angle, which was $318.1^{\circ} \mathrm{T}$ (degrees true) (Fig. 3). This angle is within $5^{\circ}$ of the mean flow of the individual moorings and the isobath orientation. All further velocities are presented in this rotated reference frame, 


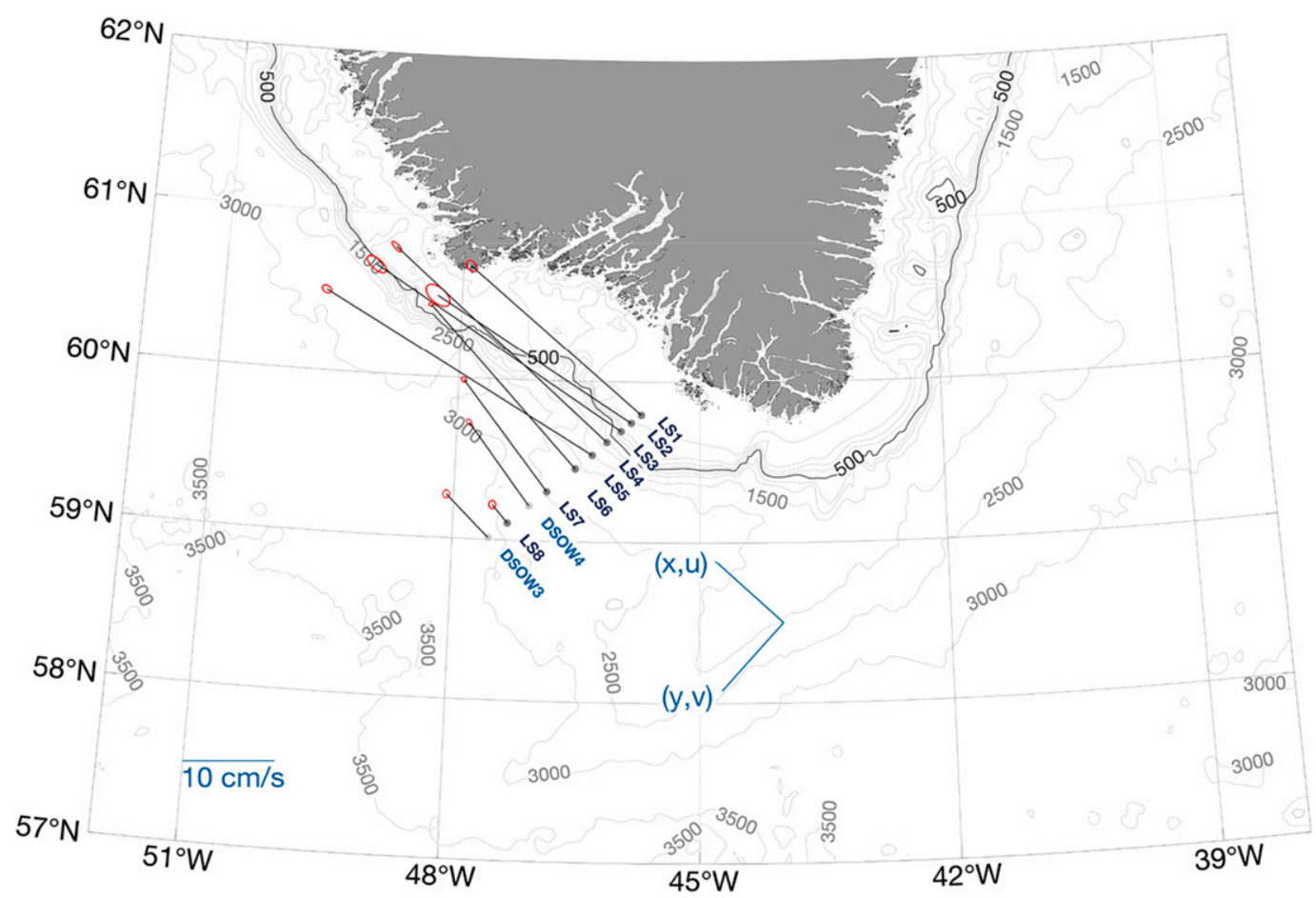

FIG. 3. Depth-mean 2014-18 velocity vectors, with standard error ellipses in red. The orientation of the rotated coordinate system is indicated.

with positive along-stream velocity $u$ directed toward the northwest and positive cross-stream velocity $v$ directed offshore toward the southwest.

\section{4) GRIDDING OF VERTICAL SECTIONS}

Hourly vertical sections were constructed for potential temperature referenced to the sea surface (hereafter referred to as temperature), practical salinity, potential density referenced to the sea surface (hereafter referred to as density), and along- and cross-stream velocity. The data were gridded using a Laplacian-spline interpolator at each time step (Smith and Wessel 1990). The final gridding has a resolution of $5 \mathrm{~km}$ in the horizontal and $100 \mathrm{~m}$ in the vertical. This was obtained by first gridding the offshore data (LS5-DSOW3) at $15 \mathrm{~km}$ in the horizontal, $200 \mathrm{~m}$ in the vertical in order to account for the larger distances between these offshore moorings, then subsequently gridding the onshore moorings along with the coarsely gridded offshore product at the higher resolution. A bound was applied over the domain to account for only the data available at each time step, including a small amount of extrapolation. For example, if the instrumentation experienced blowdown, the upper portion of the water column that was no longer sampled at that time step was not gridded, in order to avoid extrapolating into areas with no available data. The bound applied to the hydrographic data is slightly different than that applied to the velocity data, as the $100-\mathrm{m}$ ADCPs on the offshore moorings (mounted on the subsurface flotation) returned profiles of the upper water column, even when displaced vertically.

\section{b. Additional datasets}

The bathymetric data used in the vertical sections came from a shipboard survey during the initial mooring deployment in 2014, using the 12-kHz Knudsen echosounder on board the R/V Knorr. The raw bottom data were regressed and visually selected and smoothed to produce the final bottom topography utilized in this study. The bathymetric data in all base maps are ETOPO2v2 (NGDC 2006).

Additionally, the European Centre for Medium Range Weather Forecasting (ECMWF) ERA5 atmospheric reanalysis product is used to investigate the effects of atmospheric forcing - both large scale and regional features (Herbach and Dee 2016). This new product, which uses the Integrated Forecast System (IFS), has 3-hourly resolution, with $0.25^{\circ}$ grid spacing in latitude and longitude. Earlier studies have demonstrated that IFS-based reanalysis products compare favorably with observations at these latitudes (Renfrew et al. 2002, 2009).

Data from four other mooring arrays, three deployed as part of the OSNAP project and one deployed as part of an earlier field program investigating the EGC/IC south of Demark Strait (von Appen et al. 2014a) are 
used to investigate upstream connections with regard to the seasonality of the water masses in the boundary current. Processing details for the OSNAP data can be found in Lozier et al. (2019) while processing details for the northern EGC/IC array are documented in von Appen et al. (2014a).

\section{Results and discussion}

\section{a. Mean conditions}

The 4-yr mean, depth-averaged velocity vectors reveal that the predominant flow is toward the northwest, following the isobaths (Fig. 3). The flow is remarkably consistent, as seen by the small standard error ellipses marked in red (decorrelation time scales of 1-3 days, depending on the mooring). Moorings LS2 and LS8 indicate slightly higher variability in flow direction and speed; these signals will be discussed in sections $3 \mathrm{~d}(3)$ and $3 \mathrm{~d}(1)$, respectively. It is evident that the array bracketed the strongest part of the boundary current, as is shown by the weak mean flow at the offshoremost full-depth mooring (LS8) in Fig. 3. Keep in mind that moorings DSOW3 and DSOW4 (shaded in light gray in Fig. 3) occupy only the bottom $500 \mathrm{~m}$ of the water column, and therefore only measure the DWBC. The mean vertical sections presented below indicate that the array also captured the strongest flow in this deep layer.

The 2014-18 mean temperature, salinity, and alongstream and cross-stream velocity vertical sections are presented in Fig. 4. This is the first year-long rendering of the full boundary current system in the eastern Labrador Sea. The temperature and salinity sections highlight the strong gradient from warm and salty conditions offshore near the surface to cool and fresh waters on the shelf. Off the shelf, the temperature dictates the stratification, with isotherms (and therefore isopycnals) sloping downward progressing onshore as deep as $1500 \mathrm{~m}$. There are two cores of high salinity, one centered near 400-m depth, and a deeper core that slopes upward progressing onshore. The shallow core is associated with the Atlantic-origin water, while the deeper core is part of the dense overflow water from the Faroe Bank Channel and Iceland-Faroe Ridge.

The mean along-stream velocity section reveals the bottom-intensified DWBC, centered at LS7 at $2400 \mathrm{~m}$ with velocities exceeding $25 \mathrm{~cm} \mathrm{~s}^{-1}$. This deep core advects overflow waters with densities greater than $27.8 \mathrm{~kg} \mathrm{~m}^{-3}$. Inshore and above the DWBC, the surface-intensified WGC advects the Atlantic-origin water centered at LS4 and LS5, with velocities up to $80 \mathrm{~cm} \mathrm{~s}^{-1}$. This core of warm, salty water is offset vertically from the maximum WGC velocity and detached from the topography.
The WGC can be seen in Fig. 3 as the two strongest velocity vectors at LS4 and LS5. The WGC also exhibits a slight tendency toward positive cross-stream velocities, meaning that the current is angled slightly toward the interior of the Labrador Sea compared to the rest of the flow. The vertical sections in Rykova et al. (2015) showed the Atlantic-origin water banked against the topography, in contrast to Fig. $4 \mathrm{~b}$ where the maximum salinity is separated from the topography by a wedge of lower-salinity water. However, the station spacing of their data was as large as $30 \mathrm{~km}$ in the boundary current. The detached core measured here is consistent with the high-resolution shipboard hydrographic data presented by Lin et al. (2018). It is also consistent with the slightly offshore orientation of the WGC, which would move this water mass away from the topography as it progresses northward. Furthermore, the majority of the data used by Rykova et al. (2015) were collected in summer. It is shown below in section $3 \mathrm{~d}(2)$ that the banking of the IW at the OSNAP WG array against the topography is a seasonal feature, present mainly in summer. It is also possible that the position of the water mass evolves as it moves downstream. Myers et al. (2009), only using summer data, do not show high salinity waters banked against the topography at Cape Farewell, but they do observe this feature farther downstream.

The WGCC is a surface-intensified flow of cold, fresh water that is captured by LS1 and LS2, flowing at 20$30 \mathrm{~cm} \mathrm{~s}^{-1}$. In the mean the WGCC is merged with the WGC, although instantaneously it often appears as a separate core. Unfortunately, the OSNAP WG array did not extend far enough onto the shelf to bracket the coastal current. This motivated the deployment of two additional tripods inshore of LS1 when the array was serviced in 2018 (data not yet recovered).

\section{b. Water masses}

The West Greenland boundary current system advects six different water masses, which are present in varying quantities throughout the year. The water masses are as follows, progressing from shallow to deep: 1) cold and fresh Upper Polar Water (UPW), which is a mixture of buoyant outflow from the Arctic and Greenland runoff (Rudels et al. 2002; Sutherland et al. 2009)—-this occupies a wedge that extends from the shelf to roughly mooring LS5; 2) seaward of LS5, Upper Ambient Water (UAW) is found in the top $200 \mathrm{~m}$, which is a mixture of interior water and UPW that has penetrated offshore; 3 ) warm and salty Irminger Water (IW), which is the Atlanticorigin water that has circulated cyclonically in the subpolar gyre (Lazier et al. 2002; Cuny et al. 2002; Pickart et al. 2005; Myers et al. 2007); 4) weakly stratified Labrador Sea Water (LSW), which is formed by convection in the Labrador 

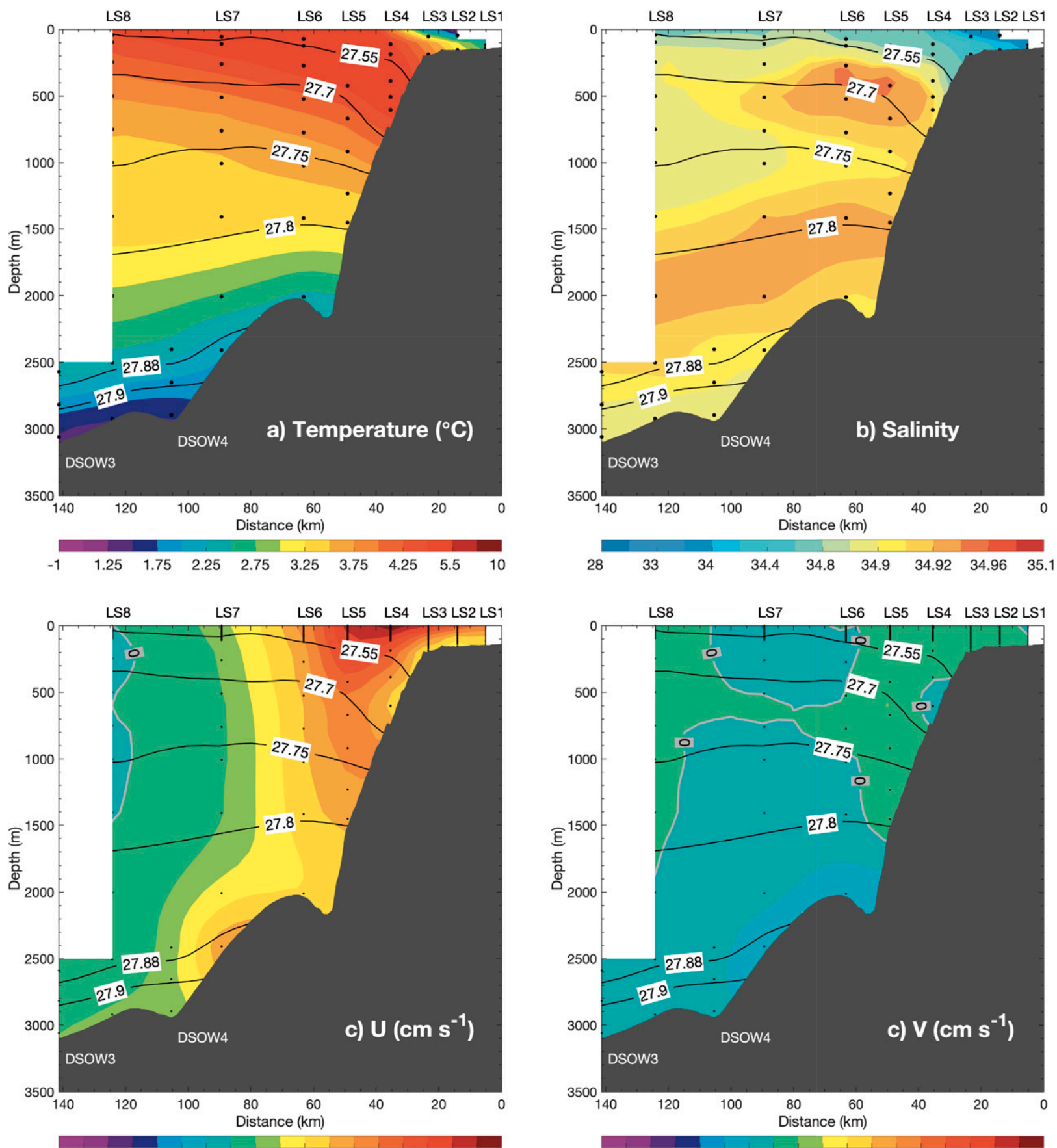

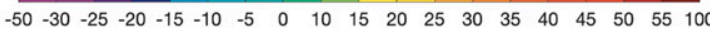

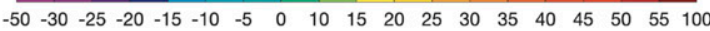

FIG. 4. 2014-18 mean vertical sections of (a) temperature, (b) salinity, (c) along-stream velocity, and (d) cross-stream velocity, with isopycnals overlaid (black contours; $\mathrm{kg} \mathrm{m}^{-3}$ ). The nominal instrument positions are indicated by the black dots. The $0 \mathrm{~cm} \mathrm{~s}^{-1}$ velocity contour (thick gray) is indicated in (c) and (d).

and Irminger Seas and exhibits low potential vorticity (e.g., Lazier et al. 2002); 5) cold and salty Northeast Atlantic Deep Water (NEADW), which enters the DWBC via the Faroe Bank Channel overflow (Lazier et al. 2002; Yashayaev and Clarke 2008) and the
Iceland-Faroe Ridge (Dickson and Brown 1994; Beaird et al. 2013); and 6) cold and dense Denmark Strait Overflow Water (DSOW) which is the densest component of the boundary current system (Dickson and Brown 1994). 
TABLE 1 . Water mass definitions used in the study; $S$ is salinity, $\sigma_{\theta}$ is potential density, and $X$ is offshore extent.

\begin{tabular}{lc}
\hline \multicolumn{1}{c}{ Water mass } & Definition \\
\hline Irminger Water (IW) & $S \geq 34.92$ and $\sigma_{\theta}<27.74 \mathrm{~kg} \mathrm{~m}^{-3}$ \\
Labrador Sea Water (LSW) & $27.68 \mathrm{~kg} \mathrm{~m}^{-3}<\sigma_{\theta}<27.8 \mathrm{~kg} \mathrm{~m}^{-3}$ and $S<34.92^{-3}$ \\
Northeast Atlantic Deep Water (NEADW) & $S>34.92$ and $\sigma_{\theta}>27.74 \mathrm{~kg} \mathrm{~m}^{-3}$ \\
Denmark Strait Overflow Water (DSOW) & $\sigma_{\theta} \geq 27.8 \mathrm{~kg} \mathrm{~m}^{-3}$ and $S<34.92$ \\
Upper Polar Water (UPW) & $S<34.92$ and $X<60 \mathrm{~km}$ \\
Upper Ambient Water (UAW) & $\sigma_{\theta}<27.68 \mathrm{~kg} \mathrm{~m}^{-3}$ and $S<34.92$ and $X>60 \mathrm{~km}$ \\
\hline
\end{tabular}

The definitions of these six water masses are given in Table 1. Given that the composition of the boundary current in this region has not been previously studied, we used upstream definitions as a first attempt at classification, but amended these values to reflect the slightly modified properties in the cores of the water masses at the OSNAP WG line. In particular, the IW and NEADW are fresher than their upstream counterparts. For IW, this is likely due to lateral mixing with LSW (e.g., Lin et al. 2018). For example, IW has previously been defined as waters between $4^{\circ}$ and $5^{\circ} \mathrm{C}$ and salinities around 34.8534.95 (Krauss 1995; Buch et al. 2004). These definitions were generally applied on the east coast of Greenland. Buch et al. (2004) cite a different water mass, which they call Irminger Mode Water (or modified Irminger Water in the case of Ribergaard 2013), that exhibits slightly colder, fresher properties than its IW counterpart due to mixing along the IW pathway. Freshening of the NEADW could result from vertical mixing with the underlying DSOW and overlying LSW (e.g., Yashayaev and Clarke 2008; Yashayaev and Dickson 2008). Additionally, it is possible that these previously used definitions are no longer appropriate, due to long-term changes to water mass properties (e.g., Myers et al. 2007).

LSW has a more established definition in the interior Labrador Sea, which we utilize here as the layer of water residing between the $27.68 \mathrm{~kg} \mathrm{~m}^{-3}$ and $27.8 \mathrm{~kg} \mathrm{~m}^{-3}$ isopycnals (e.g., Clarke and Gascard 1983; Lazier et al. 2002; Pickart et al. 2003a,b). In previous studies, a distinction was made between upper and deep (also known as classical) LSW in order to represent waters formed convectively in the vicinity of the boundary current as opposed to the interior basin (Rhein et al. 1995; Pickart et al. 1996, 1997, 2002). For the purposes of this study, we will not distinguish between vintages of LSW, as we seek to address the seasonality of all recently formed LSW, regardless of origin. DSOW has historically been classified as all water denser than $27.8 \mathrm{~kg} \mathrm{~m}^{-3}$ (Dickson and Brown 1994), or sometimes more strictly as water denser than $27.88 \mathrm{~kg} \mathrm{~m}^{-3}$ (Tanhua et al. 2005). Here we require that DSOW be denser than $27.8 \mathrm{~kg} \mathrm{~m}^{-3}$, but, as shown below, some of the NEADW is within this isopycnal layer as well.
Computationally, we documented the water masses present at the OSNAP WG line over the 4-yr period as follows. For each hourly vertical section, the grid points associated with the water masses in Table 1 were identified. We note that water masses are not classified solely by isopycnal bounds. For example, NEADW is bounded by an isohaline at its deepest extent, which is often denser than $27.8 \mathrm{~kg} \mathrm{~m}^{-3}$. Therefore, it is not until the NEADW has been identified that all of the remaining water denser than $27.8 \mathrm{~kg} \mathrm{~m}^{-3}$ is assigned to DSOW. This assures that the relatively salty overflow water from the Faroe Bank Channel/Iceland-Faroe Ridge is not mistakenly identified as originating from Denmark Strait. Similarly, the boundary between NEADW and LSW corresponds to an isohaline, which assures that the relatively light, and fresh, LSW is not identified as overflow water.

The resulting volumetric temperature-salinity (TS) diagram for the 4-yr deployment is shown in Fig. 5a. The light upper waters (UPW and UAW) account for the large spread in properties fresher than 34.92. These water masses exhibit a large seasonal cycle in hydrographic properties, as might be expected of surface waters directly subject to varying atmospheric forcing. Focusing on the denser waters (Fig. 5b), one sees the volumetric modes (i.e., $T / S$ bins most commonly sampled by the moorings) associated with LSW and DSOW. In addition, there are large amounts of IW and NEADW. This demonstrates that a sizable fraction of the water denser than $27.8 \mathrm{~kg} \mathrm{~m}^{-3}$ stems from the Faroe Bank Channel and Iceland-Faroe Ridge.

To quantify the distribution of the water masses in the vertical, the percentage of time that each grid point sampled a given water type was tallied over the 4-yr mooring deployment (Fig. 6). The IW, corresponding to the warmest and saltiest water in the boundary current, is found in the middepth portion of the WGC, spanning moorings LS4-LS6. The LSW is found in high concentrations on the offshore side of the array, particularly at LS 8 between 500 and $1500 \mathrm{~m}$. It corresponds to a minimum in planetary potential vorticity, as would be expected for recently ventilated water (McCartney and Talley 1984). However, this vorticity signal is too noisy to use as a robust diagnostic to define the LSW. Notably, 
a) full TS

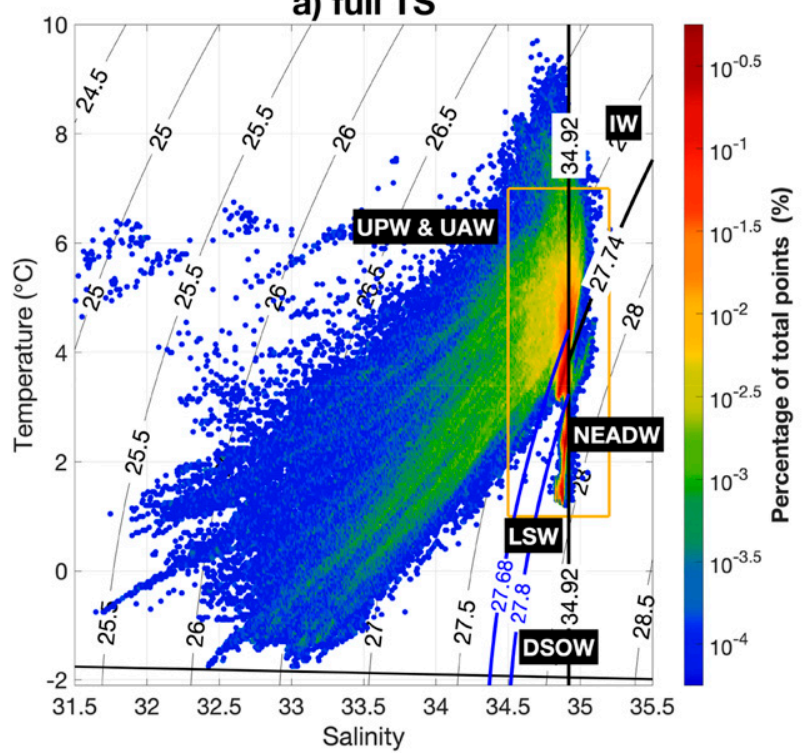

b) enlarged TS

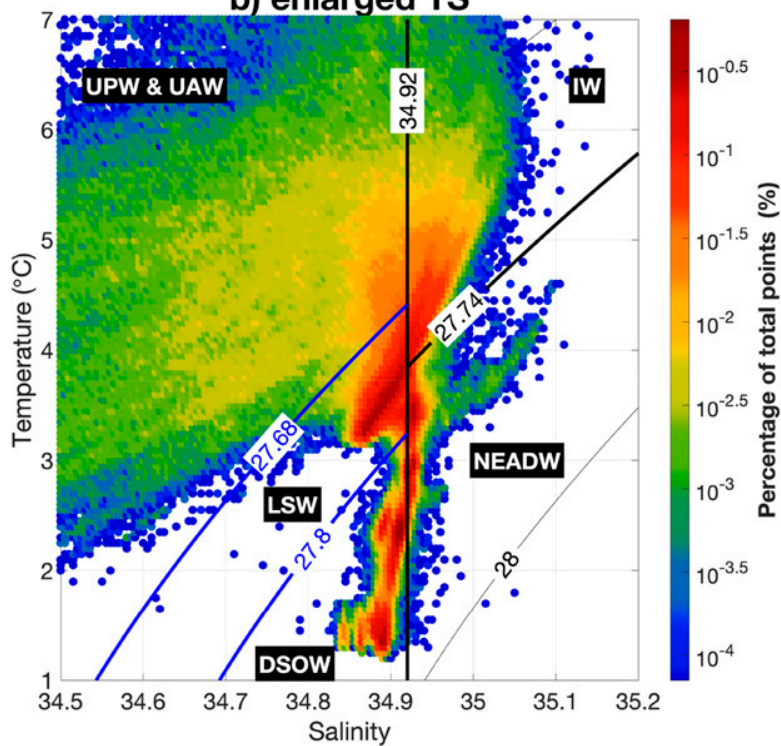

FIG. 5. (a) 2014-18 volumetric TS diagram, with the identified water masses labeled (see Table 1). UPW and UAW cannot be separated purely in TS space so an offshore distance criterion was also utilized in their definition. The yellow rectangle encompasses the region highlighted in (b). (b) An enlarged view of the densest water masses. Note the logarithmic color axis.

there is a large LSW presence at mooring LS5 within the deepest part of the WGC, which is discussed further in section $3 \mathrm{~d}(1)$. Below the IW, the deep salinity maximum of the NEADW is present in large quantities between 1250 and $2250 \mathrm{~m}$. Below the NEADW, the DSOW is transported by the core of the DWBC and occupies the water column deeper than $2250 \mathrm{~m}$.

\section{c. Volume transport}

The 4-yr mean volume transport across the full array, computed by calculating the hourly transport and subsequently averaging these data, is $31.1 \pm 7.4 \mathrm{~Sv}(1 \mathrm{~Sv} \equiv$ $\left.10^{6} \mathrm{~m}^{3} \mathrm{~s}^{-1}\right)$, where the uncertainty is the standard deviation. The calculated integral time scale is 3 days, which results in a standard error of $0.4 \mathrm{~Sv}$. The closest comparison to this mean value is the average transport reported by Pickart and Spall (2007) using repeat occupations of the AR7W section from 1990 to 1997, adjusted with an inverse constraint. They computed a mean transport of $35.5 \mathrm{~Sv}$. However, they did not have data shoreward of the 700-m isobath. Subtracting the transport measured here inshore of that isobath reduces our 4 -yr value to $30.1 \mathrm{~Sv}$. The discrepancy between our value and the Pickart and Spall (2007) estimate ( 30.1 vs $35.5 \mathrm{~Sv}$ ) is sizable. However, the Pickart and Spall (2007) value is far less robust (computed using 10 vertical sections versus more than 30000 hourly vertical sections in our mooring dataset), and the spatial coverage is different. Nonetheless, the Pickart and Spall (2007) value falls within the envelope of one standard deviation of the transport calculated in this study.
The Lagrangian float study of Lavender et al. (2000) revealed the presence of a trough of absolute dynamic topography encircling the Labrador Basin, just offshore of the boundary current system. This corresponds to a series of cyclonic recirculation gyres that abut the boundary current. One of the gyres is situated offshore of the OSNAP WG array (see also Pickart and Spall 2007). In the along-stream velocity section of Fig. 4, one sees that the zero-velocity contour is located just shoreward of mooring LS8. This implies that, in the mean, our mooring array captured the northward limb of this local recirculation gyre (instantaneously, this is not always the case). Here we take the boundary between the recirculation gyre and the boundary current to be the velocity contour corresponding to $10 \%$ of the maximum along-stream flow of the WGC at every time step. In the mean this corresponds to a value of approximately $8 \mathrm{~cm} \mathrm{~s}^{-1}$. This is a reasonable choice in light of the results of Pickart and Spall (2007), who were able to determine this boundary objectively because their section extended across the entire basin and balanced mass. Further rationale for our choice is presented below in section $3 \mathrm{~d}(1)$.

The mean transports (boundary current and recirculation) for the different water masses computed using the OSNAP WG array are presented in Table 2, based on the water mass definitions in Table 1 . While numerous previous studies have estimated the transport of the different components of the West Greenland boundary current system, only a select number have broken this 

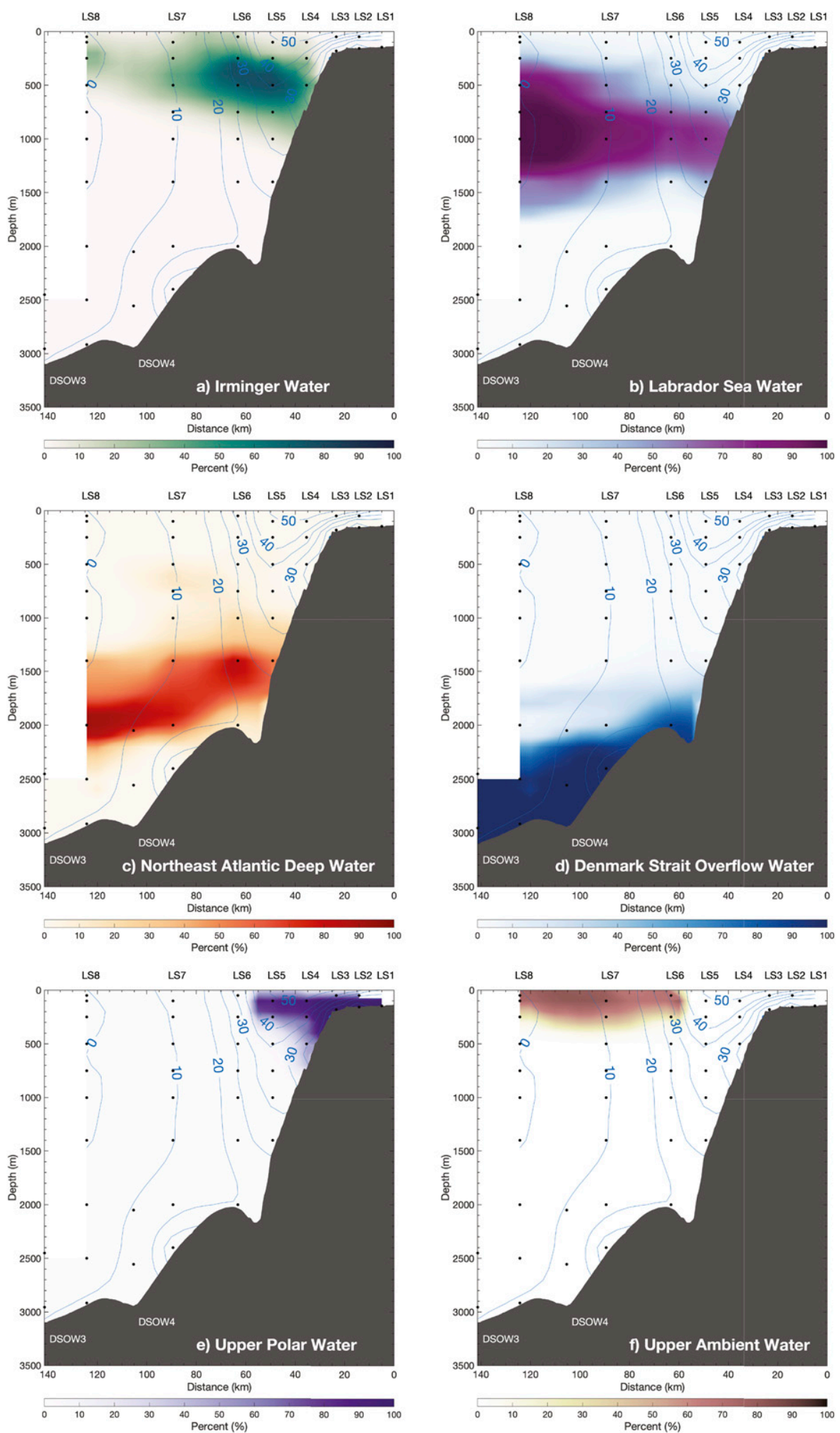

FIG. 6. Locations of the six water masses sampled. The percentage (\%) of time that each grid point sampled a particular water mass over the 4 -yr period is tallied. 
TABLE 2. Four-year mean transports of the different water masses, with their standard deviations, separated into the boundary current portion and the recirculation portion. The standard errors are presented in parentheses.

\begin{tabular}{lcc}
\hline \hline \multicolumn{1}{c}{ Water mass } & $\begin{array}{c}\text { Boundary current } \\
\text { transport }(\mathrm{Sv})\end{array}$ & $\begin{array}{c}\text { Recirculation } \\
\text { transport }(\mathrm{Sv})\end{array}$ \\
\hline Total & $29.9 \pm 7.1(0.3)$ & $1.2 \pm 2.4(0.2)$ \\
IW & $5.6 \pm 3.8(0.6)$ & $0.1 \pm 0.3(0.02)$ \\
NEADW & $5.5 \pm 3.3(0.5)$ & $0.4 \pm 0.6(0.04)$ \\
LSW & $7.5 \pm 3.9(0.5)$ & $0.3 \pm 1.4(0.06)$ \\
DSOW & $5.0 \pm 2.4(0.3)$ & $0.5 \pm 0.5(0.02)$ \\
UPW & $4.3 \pm 1.7(0.2)$ & $0.01 \pm 0.06\left(8.8 \times 10^{-4}\right)$ \\
UAW & $2.0 \pm 1.5(0.1)$ & $0.01 \pm 0.5(0.02)$ \\
$\sigma_{\theta}>27.8 \mathrm{~kg} \mathrm{~m}^{-3}$ & $8.3 \pm 2.8(0.2)$ & $0.8 \pm 0.8(0.04)$ \\
\hline
\end{tabular}

down by water mass constituents. Hence, there is limited basis for comparison with the results presented here. The exception is the transport of overflow water. According to the historical definition of overflow water (denser than $27.8 \mathrm{~kg} \mathrm{~m}^{-3}$, Dickson and Brown 1994), we calculate $8.3 \pm 2.8 \mathrm{~Sv}$, compared to $10.8 \pm 4.9 \mathrm{~Sv}$ calculated at the OSNAP East line northeast of Cape Farewell using the first two years of data (Hopkins et al. 2019). Using only the first two years of WG data, to be consistent with the Hopkins et al. (2019) study, the boundary current overflow water transport is $8.8 \pm 2.8 \mathrm{~Sv}$ at OSNAP WG. Although the standard deviations are large, this suggests that there is a net loss in transport of the dense water as it rounds Cape Farewell and interacts with Eirik Ridge, consistent with the results of Holliday et al. (2009) who computed a $30 \%$ recirculation of transport in this density class at Cape Farewell. It is also in line with the findings of Hall et al. (2013) who computed a transport of $8.6 \mathrm{~Sv}$ on the eastern end of the AR7W line for waters denser than $27.8 \mathrm{~kg} \mathrm{~m}^{-3}$. The total transport of NEADW and DSOW found here is $10.5 \pm 3.9 \mathrm{~Sv}$ (Table 2). We conclude, then, that waters stemming from the overflows across the Greenland-Scotland Ridge contribute $2.2 \mathrm{~Sv}$ more than one would obtain with the historical density definition. Interestingly, our results imply a similar contribution (after entrainment) from the eastern overflow versus the western overflow: $5.5 \pm 3.3$ for the NEADW versus $5.0 \pm 2.4$ for the DSOW.

The yearly time series of boundary current transport for the different water mass components, along with the total boundary current transport, are shown in Fig. 7, where a 30-day low pass has been applied. While the total transport of the West Greenland boundary current system does not exhibit a seasonal signal, the individual water mass components do. This is because the individual components compensate each other. For example, when the transport of IW is strong, the transport of LSW is weak (cf. Figs. 7a,b, which is discussed in more detail in section 3d). Additionally, when the transport of NEADW declines, the transport of DSOW increases (cf. Figs. 7c,d). This transport variability, as well as
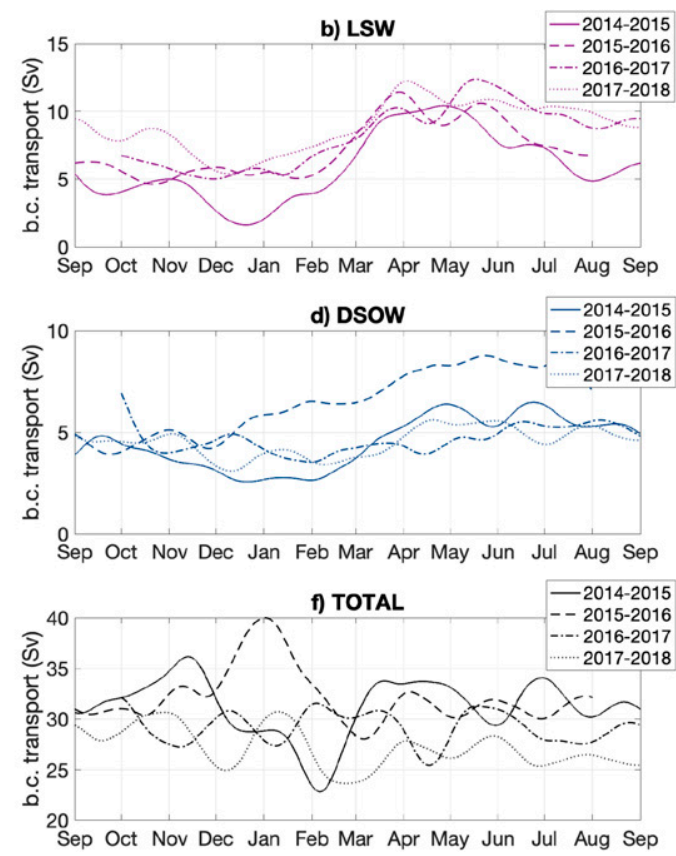

Sep Oct Nov Dec Jan Feb Mar Apr May Jun Jul Aug Sep
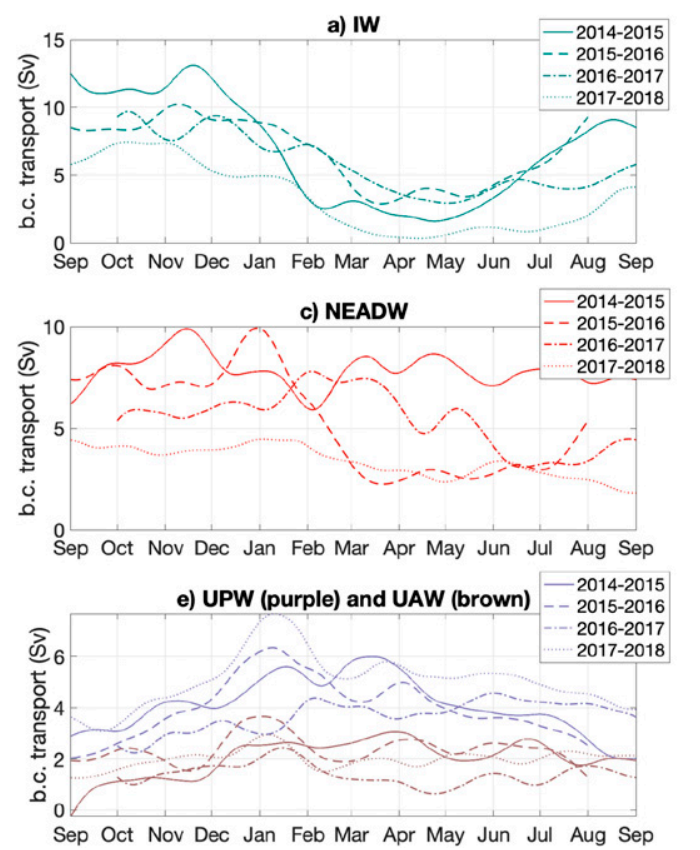

FIG. 7. 2014-18 boundary current transport time series for the individual water mass components, as well as the total boundary current transport. The hourly data have been low-pass filtered with a 30-day Butterworth filter. Each year is plotted with a different line type (see the legend). 

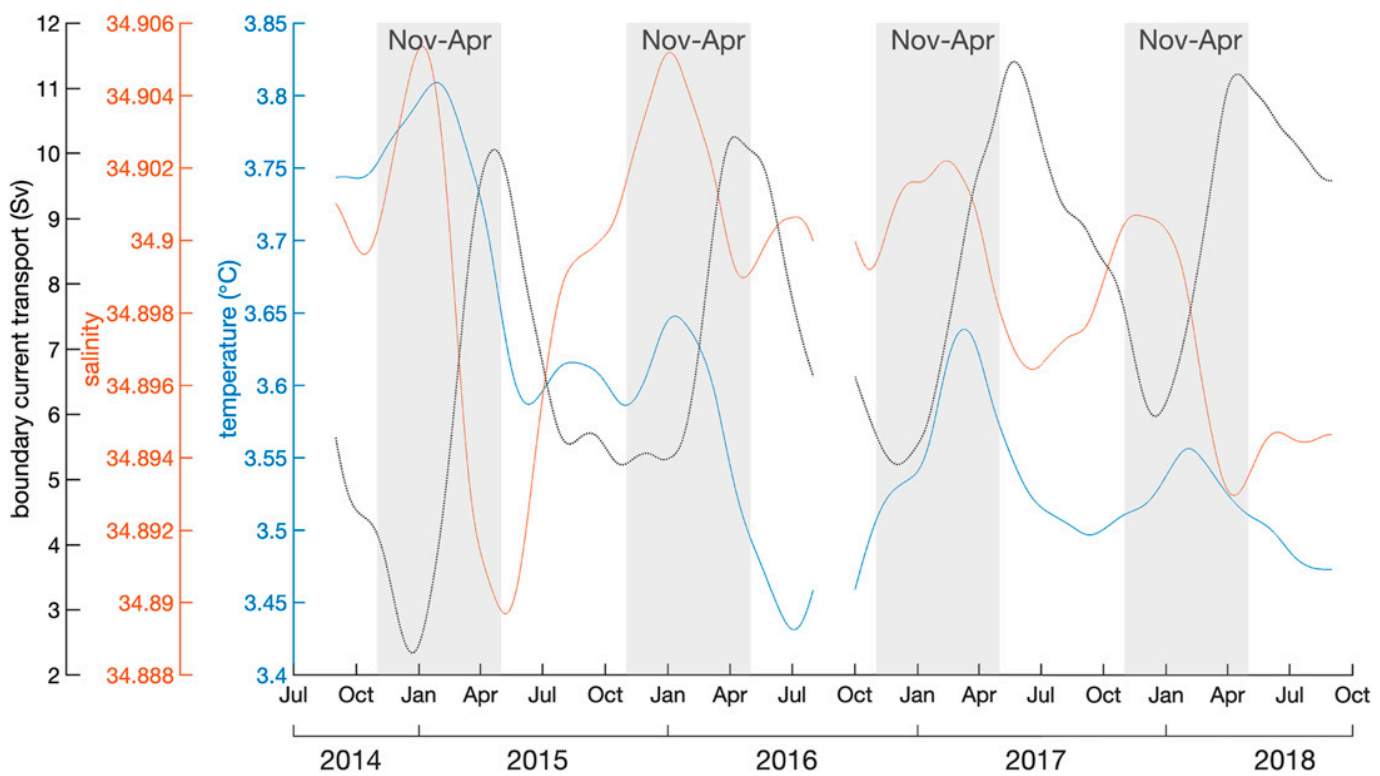

FIG. 8. Temperature, salinity, and transport of LSW low-passed with a 60-day Butterworth filter. For ease of presentation, the cold months of the year (November-April) are indicated by gray shading. The data gap in August 2016 is due to the mooring turnaround.

the variability in hydrographic properties, motivate a seasonal analysis of the boundary current system to understand how its composition and transport vary on a month-to-month basis. This will shed light on the production and export of ventilated waters and the seasonal transformation of these waters.

\section{d. Seasonality}

\section{1) LABRAdor SEA WATER}

Using all of the grid points defined as LSW, the mean temperature, salinity, and boundary current transport were computed hourly, and the resulting time series were low-pass filtered using a 60-day second-order Butterworth filter to highlight the seasonal variability (Fig. 8). This reveals that the LSW is coldest and freshest in spring (May-July), slightly after its transport peaks in April/May. The hydrographic signal is consistent with active convection ventilating the LSW during the previous winter. Notably, the changes in transport are predominantly due to increases in the amount of LSW present (referred to from here on as area), not to changes in the velocity of the LSW.

Seasonal renditions of the bin count tallies shown in Fig. 6 indicate that, during the winter months, LSW is prevalent at the offshore end of the array (LS7 and LS8), but can also be found within the WGC. In fact, at times there are two distinct cores of LSW-one within the WGC and one at the edge of the array-with a minimum between the two features (Fig. 9a). In this configuration the large offshore presence of LSW is confined to the recirculation gyre. The gyre tends to trap water, allowing it to be subject to air-sea heat loss for a sustained period. Deep mixed layers are indeed found locally within the gyre (Lavender et al. 2002). Figure 9a offers further justification for our choice of the boundary between the gyre and the boundary current (note the $8 \mathrm{~cm} \mathrm{~s}^{-1}$ velocity contour in the figure).

The double core structure of Fig. 9a implies that there is an upstream source of LSW that is distinct from the LSW in the neighboring recirculation gyre that enters the current through mixing/entrainment. The instances of two cores are intermittent and account for approximately $25 \%$ of the $4-y r$ record. Interestingly, these occurrences tend to be present in early winter, well before the springtime peak in LSW transport. Later in the season there is a single core (Fig. 9b), which indicates that LSW is penetrating into the boundary current from offshore.

To investigate this further, we divided the LSW signal into $\mathrm{LSW}_{\mathrm{bc}}$ and $\mathrm{LSW}_{\text {recirc }}$, where the subscripts represent whether the water mass is found within the WGC or within the adjacent recirculation gyre, using the $10 \%$ velocity criterion as described above. This partitioning demonstrates that the seasonal timing of the hydrographic signal remains the same whether the water is within the boundary current or gyre (not shown). However, the LSW within the boundary current tends to be slightly warmer and saltier. The $\mathrm{LSW}_{\mathrm{bc}}$ transport dominates that of $\mathrm{LSW}_{\text {recirc }}$ : the 4-yr mean transport 

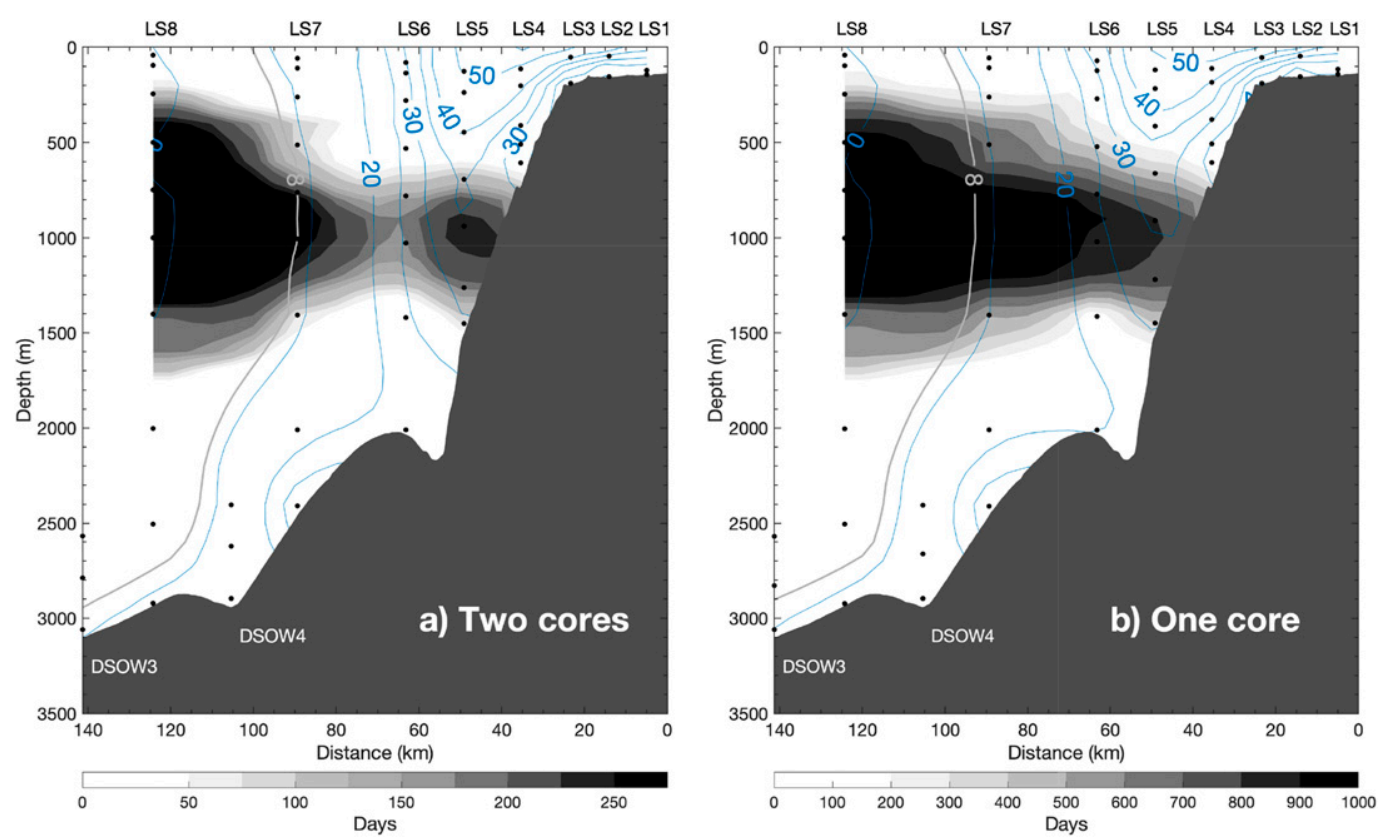

FIG. 9. Number of days (gray shading) with (a) two cores of LSW and (b) one core of LSW, with the mean velocity contours in the two periods overlaid (blue contours). The $8 \mathrm{~cm} \mathrm{~s}^{-1}$ velocity contour is shown in gray, which corresponds to the mean division between the boundary current and adjacent recirculation gyre (see text). Note the different gray-shading scales in the two panels.

of $\mathrm{LSW}_{\mathrm{bc}}$ is $7.5 \pm 3.9 \mathrm{~Sv}$ compared to $0.3 \pm 1.4 \mathrm{~Sv}$ for

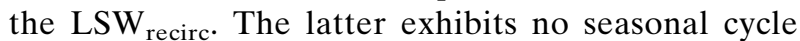
and has minimal variability. We note that, a priori, this large difference was not obvious because the area of the $\mathrm{LSW}_{\text {recirc }}$ is far greater than that of the $\mathrm{LSW}_{\mathrm{bc}}$ (Fig. 6). Hence, even though the $\mathrm{LSW}_{\mathrm{bc}}$ transport dominates because of its velocity signal (due to the seasonality in LSW presence in the fast-moving core of the WGC), its variability in transport-and that of the total LSW-is due to its area signal.

What is the origin of the LSW within the core of the WGC that did not emanate locally from mixing/entrainment from the recirculation gyre? Le Bras et al. (2020) demonstrate that newly ventilated LSW enters the boundary current east of Cape Farewell due to along-isopycnal ventilation, i.e., via isopycnals that outcrop seaward of the boundary current in the interior of the Irminger Sea. They identify two water masses, upper and deep Irminger Sea Intermediate Water, the latter of which is similar in definition to our LSW. Le Bras et al. (2020) argue that both types of newly ventilated water penetrate the boundary current through eddy exchange. It is likely that the LSW we observe within the WGC at OSNAP WG (the inner core in Fig. 9a) is advected in the boundary current around Cape Farewell. Recall that the inner core tends to be present early in the winter, before the extensive local penetration of LSW occurs from the recirculation gyre (Fig. 9b).
An explanation for this is that LSW production in the southwest Irminger Sea is driven by the forward Greenland tip jet, which causes strong air-sea heat fluxes (Våge et al. 2008). In contrast, the heat fluxes in the eastern Labrador Sea due to the basin-scale westerly winds are more moderate, since the air has warmed so far from the Labrador landmass. Hence, convection on the eastern side of Cape Farewell may develop more rapidly than that on the western side - although as the winter season progresses, the convection within the recirculation gyre clearly dominates (Fig. 9b).

\section{2) IRMINGER WATER}

The temperature, salinity, and transport time series of the IW are shown in Fig. 10. All of the IW properties exhibit peak values in midfall, between September and November, and minima in late winter, between March and May. IW originates in the North Atlantic Current as subpolar mode water formed during the winter months (McCartney and Talley 1982, 1984; McCartney 1992) and circulates around the subpolar gyre, eventually progressing into the Irminger and Labrador Seas in the upper portion of the water column (Krauss 1995; Cuny et al. 2002; Våge et al. 2011). It is of interest to understand what sets the seasonal timing of the IW observed at the OSNAP WG site. Specifically, where and how are these properties set and when were the waters last in direct contact with the atmosphere? 

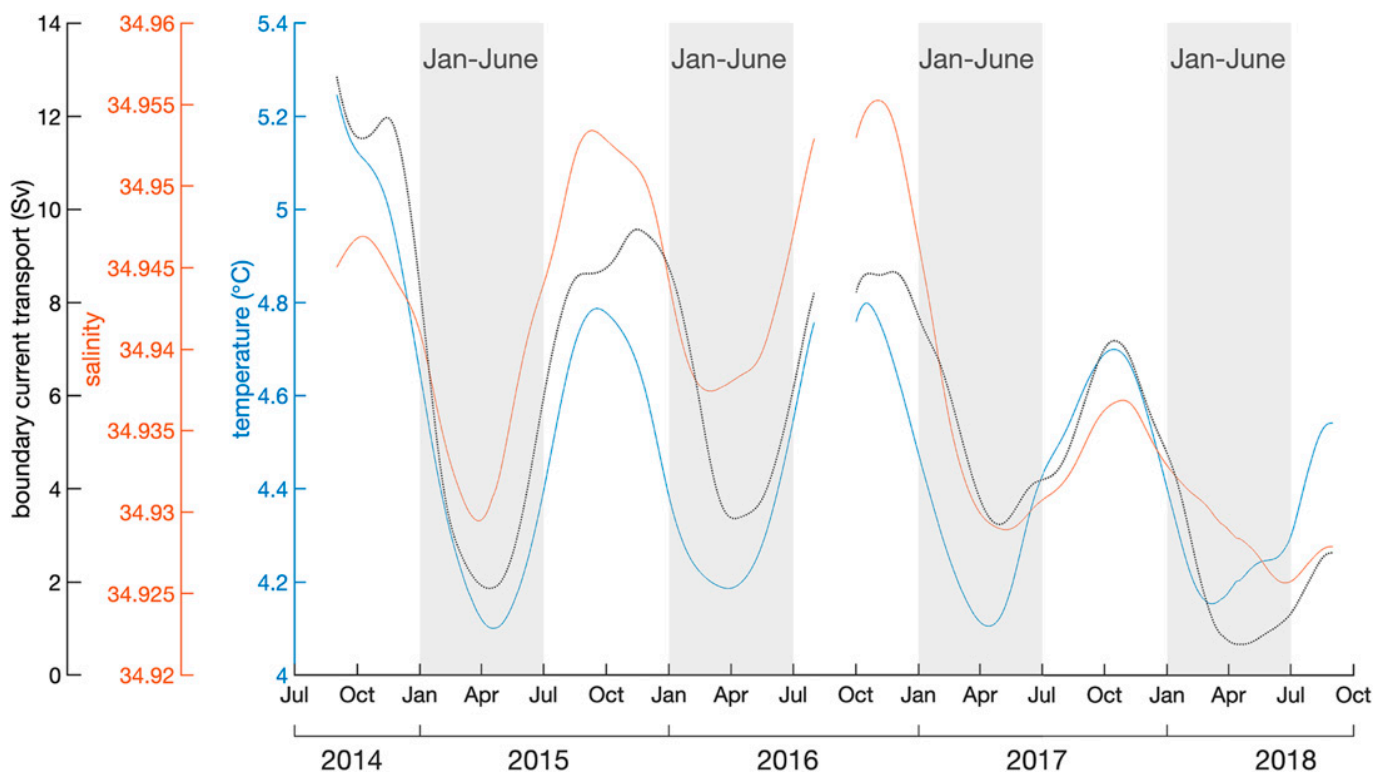

FIG. 10. As in Fig. 8, but for IW. For ease of presentation, the periods of minimum temperature, salinity, and transport have been highlighted (January-June).

To address this, we utilize data from five mooring arrays to investigate the seasonal signal of IW around the perimeter of the Irminger Sea (Fig. 11). The arrays MA1, MA2, and MA4 are also part of the OSNAP mooring line, and thus are synchronous in time with our measurements (2014-16). The MA3 array was deployed from 2007 to 2008 (von Appen et al. 2014a,b; Harden et al. 2014a). At each array we identified a mooring in the core of IW (indicated by the black circles in Fig. 11). The temperature, salinity, and density records at these sites revealed sustained wintertime convection down to at least $500 \mathrm{~m}$ at MA1, MA2, and MA3.

An example of this is shown in Fig. 12 for the MA3 array, which contained moored CTD profilers. The development of the winter mixed layer over the course of the deployment can be seen by the cooling, freshening, and densification of the surface warm and saline layer. By the end of April the mixed layer had deepened to 500-600 m, ventilating the IW. The same thing occurred at MA1 and MA2 (which was deduced using discrete TS sensors). At MA4, intermittent vertical convection was observed down to $300 \mathrm{~m}$ for periods of 1-2 weeks at a time. Le Bras et al. (2020) demonstrated that the IW at this array is also ventilated laterally due to the outcropping of isopycnals seaward of the boundary current, as noted above. These results demonstrate that the IW is directly ventilated during winter along its pathway around the Irminger Sea. At each site along the pathway the mixed layer product is colder, fresher, and denser than at the previous array. This is in agreement with the study of Brambilla et al. (2008) that documented the evolution of this mode water, using historical shipboard data, as it circulated around the subpolar gyre, as well as with the coupled modeling and observational results of Grist et al. (2014).

At MA5 (the OSNAP WG array), however, there is no evidence of local convection into the IW layer at any of the moorings. This is because, between MA4 and MA5, the IW has subducted to a depth of $500 \mathrm{~m}$ and is capped by a layer of fresh water (UPW; Fig. 4b). This layer, together with the more moderate atmospheric forcing in the eastern Labrador Sea, prohibits convection from penetrating into the IW layer. Consistent with

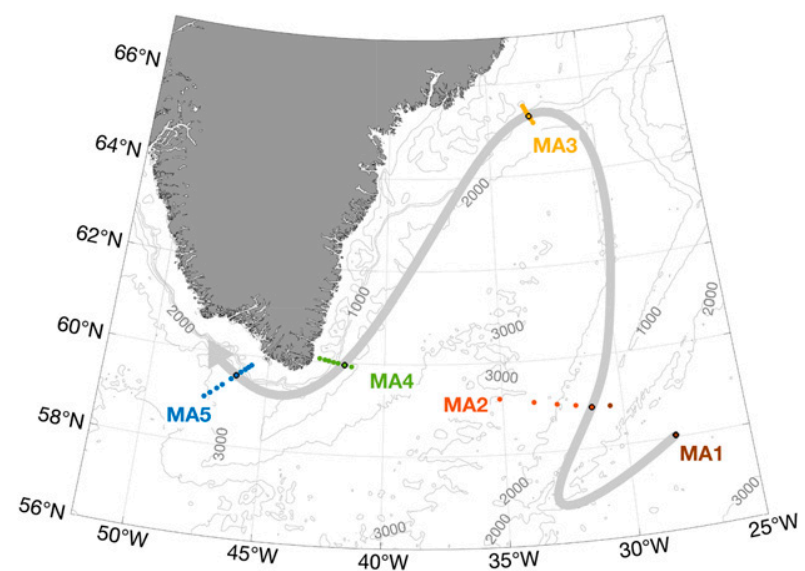

FIG. 11. The five mooring arrays used in the seasonal analysis of IW. The shaded arrow represents the schematic pathway of the boundary current. The specific mooring in the core of the IW at each array is outlined in black. MA5 is the OSNAP WG array. 
a) temperature

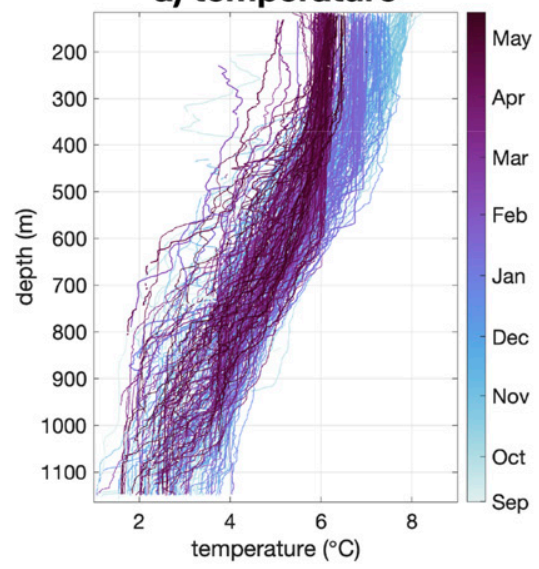

b) salinity

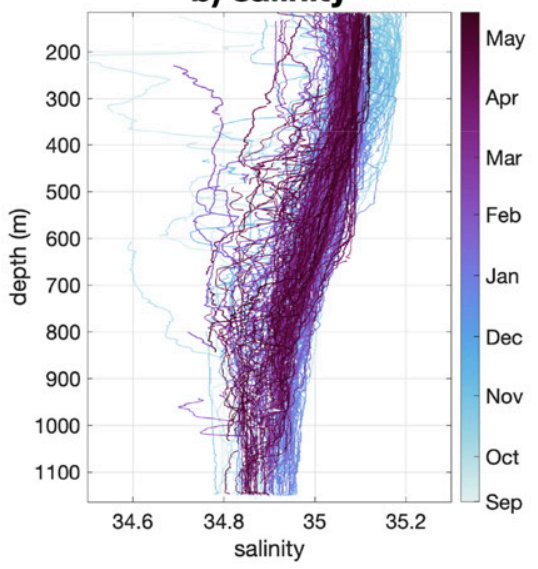

c) density

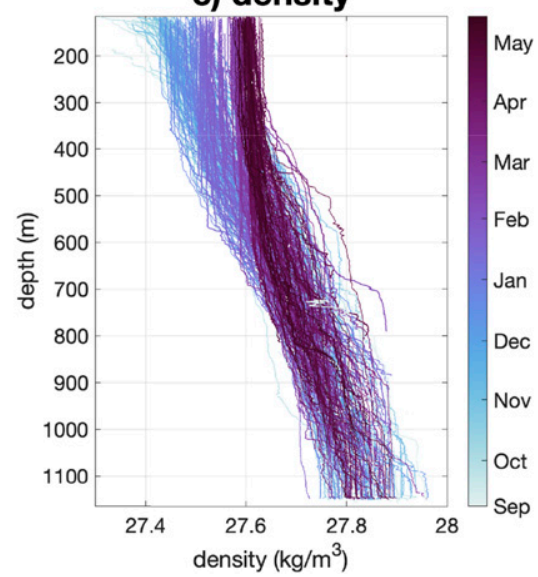

FIG. 12. Profiles of (a) temperature, (b) salinity, and (c) density every $6 \mathrm{~h}$ at the mooring in the central part of the IW at array MA3 (circled black in Fig. 11). The profiles are shaded by date from September through May.

this subduction of IW, the midfall maxima of IW properties found at MA5 are roughly in-phase with the seasonality of the Atlantic-origin water measured at Davis Strait (e.g., Curry et al. 2014). On the Labrador slope the air-sea heat fluxes are strong enough that the IW layer is ventilated there (Pickart et al. 2002). The pronounced freshwater surface layer (UPW) at the OSNAP WG site, which inhibits ventilation of the IW, is thought to be due in part to freshwater emanating locally from the shelf. Lin et al. (2018) demonstrated that the coastal current is diverted to the edge of the shelf as it rounds Cape Farewell, and that baroclinic instability can flux the freshwater offshore from the WGCC to the surface of the WGC.

These results suggest that the seasonal IW signatures of temperature and salinity at the OSNAP WG array, documented in Fig. 10, are determined by the cumulative ventilation that occurs upstream in the Irminger Sea, with the final characteristics being set in the region of MA4. Comparing the seasonal signals of IW temperature, salinity, and density at MA4 and MA5, the lagged correlations of these properties exhibit peak values at 20 days, significant at the $95 \%$ confidence level. The distance between MA4 and MA5 along the pathway in Fig. 11 is roughly $350 \mathrm{~km}$. This implies an advective speed of approximately $20 \mathrm{~cm} \mathrm{~s}^{-1}$, which is consistent with the velocity signature of the IW in the EGC/IC and WGC.

The IW transport at OSNAP WG exhibits the same seasonal signal as the temperature and salinity, with maximum values in fall and minimum values in spring (Fig. 10). As with LSW, the variability in transport of IW is driven by changes in the amount of the water present (cross-sectional area), not by changes in its velocity. Comparing the transports and areas of the two water masses reveals that they are out of phase (Figs. 13a,b).
This is due to the fact that, when the IW is freshened and cooled during winter, part of it is converted to LSW. As described above, some of this conversion is due to the strong atmospheric forcing directly ventilating the IW layer in the boundary current. The remaining conversion is due to LSW laterally mixing into the boundary current from the recirculation gyre in late spring and modifying the IW. Both mechanisms lead to less transport of IW and greater transport of LSW, hence the out of phase relationship between the two time series-driven by the cross-sectional area of the two water masses (Fig. 13b).

We return to the fact that Rykova et al.'s (2015) results show the IW banked against the topography in the WGC, whereas in our mean section the IW is isolated in a core between 400 and $600 \mathrm{~m}$ without connection to the topography (Fig. 4b). Inspection of our time series of vertical sections reveals that, in late summer and early fall, the IW does make contact with the topography intermittently. This is the time period when the IW is warmest, saltiest, and greatest in transport (Fig. 10). However, over the course of the winter, as this water is modified and some of it transformed into LSW, this newly formed LSW occupies the bottom portion of the WGC and replaces the IW as the water mass banked against the topography. Since most of the hydrographic sections used by Rykova et al. (2015) were occupied in summer, their mean fields were biased toward the configuration where IW is in contact with the topography.

\section{3) UPPER POLAR WATER}

The temperature and salinity of the UPW at the OSNAP WG array exhibit maxima in October-November and minima in March-April of each year (Fig. 14). When the UPW is coldest and freshest its transport is greatest. As with the IW, we seek to determine what factors 

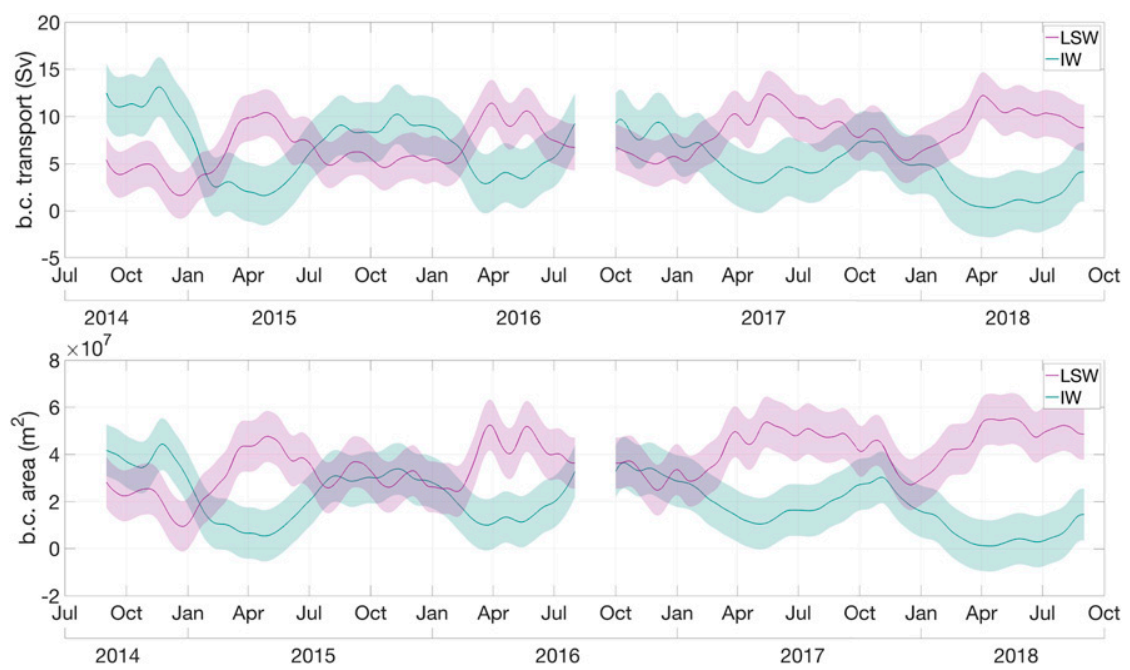

FIG. 13. (a) Time series of LSW and IW transport, with standard deviation shaded. (b) Time series of area of LSW and IW, with standard deviation shaded. The data gap in August 2016 is due to the mooring turnaround.

dictate this seasonal timing. Importantly, we note that, unlike the LSW and IW, the transport of UPW is influenced by both the speed of the water and its crosssectional area.

Previous studies have demonstrated that the transport of polar water in the EGCC is dependent on the along-stream wind stress, both through local and remote forcing. With regard to the former, downwellingfavorable winds along the east coast of Greenland intensify the EGCC via Ekman setup (Sutherland and Pickart 2008; Daniault et al. 2011). With regard to the latter, the sea surface height anomaly generated by such winds trigger coastally trapped waves which propagate southward and lead to the enhancement of the EGCC downstream of the region of strong winds (Harden et al. 2014a,b, 2016; Le Bras et al. 2018). Seasonally, the wind stress field peaks in fall in the Irminger Sea, which is consistent with the increased EGCC transport measured at the MA4 array during that season (Le Bras et al. 2018). We now investigate the role of wind forcing for the WGCC using the ERA5 wind stress fields.
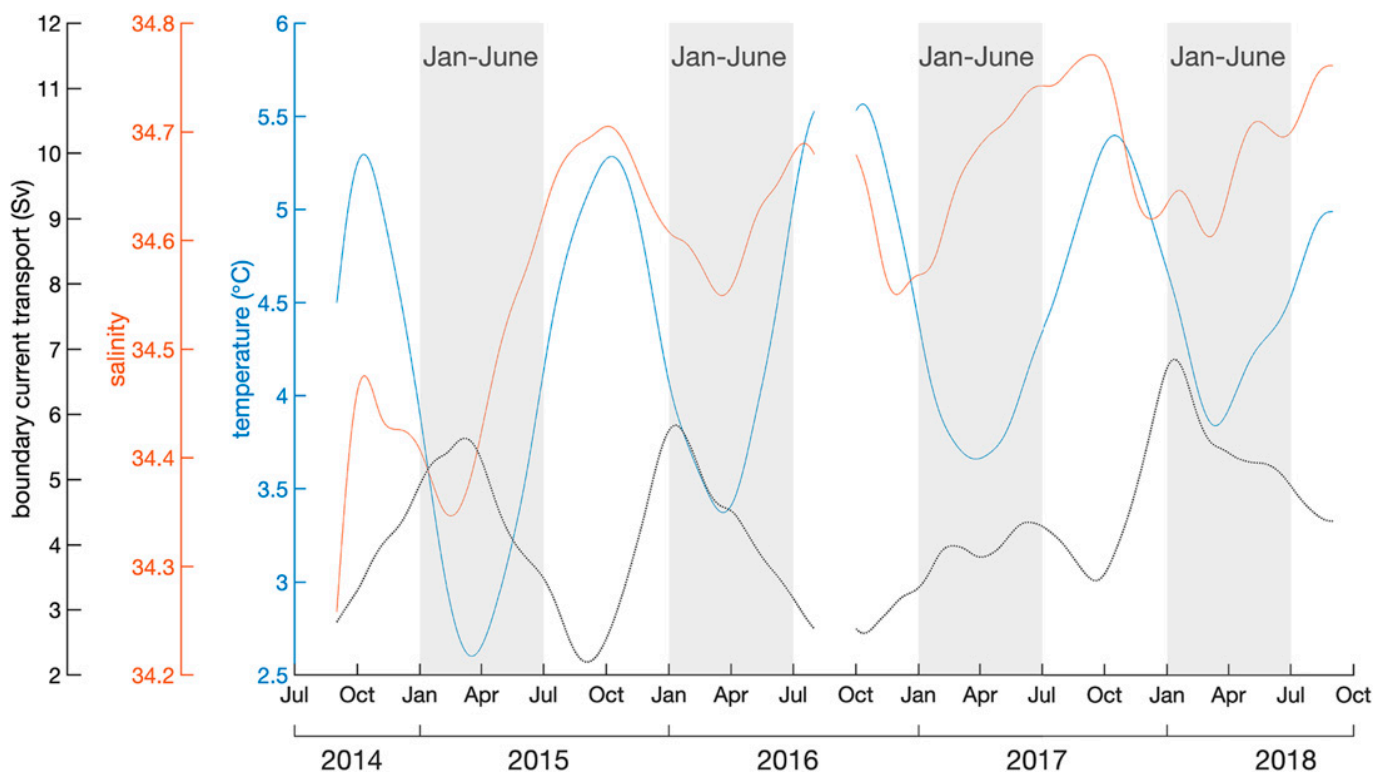

FIG. 14. As in Fig. 8, but for UPW. For ease of presentation, the winter and spring months have been highlighted (January-June). 

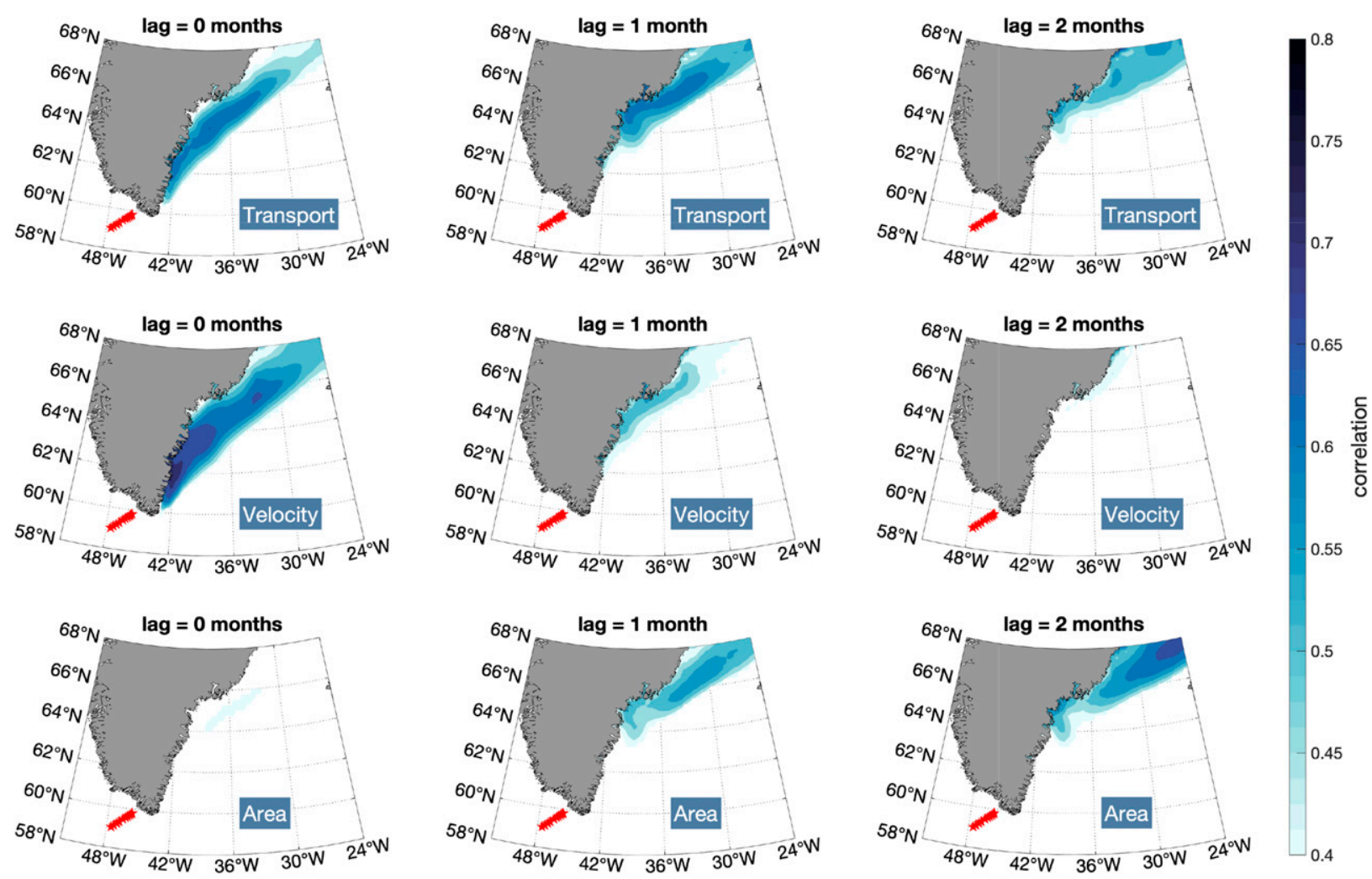

FIG. 15. Correlation maps of monthly mean UPW (top) transport, (middle) velocity, and (bottom) area with along-stream wind stress. Positive along-stream wind stress is oriented along the coast of East Greenland. Positive correlation indicates wind stress leads the signal at the mooring array. Only regions of correlations with $p$ value $<0.01$ are shaded.

We considered first if the local winds influence the UPW transport at the OSNAP WG site. Using the component of wind stress parallel to the West Greenland coast, the velocity of UPW and the wind stress were compared. This revealed that there is indeed a UPW response to intensification of local winds on synoptic time scales (less than a day). This is presumably driven by storms: for example the reverse Greenland tip jet (Moore and Renfrew 2005; Martin and Moore 2007; Ohigashi and Moore 2009), which would lead to downwelling events and Ekman set up that would impact the along-stream UPW velocity. On seasonal time scales, however, which is our interest here, there is no evidence of a local response.

Next, we considered remote forcing associated with the barrier winds along the east coast of Greenland. Specifically, we correlated the monthly mean UPW transport values at $0-, 1-$, and 2-month lags with the 30-day low-passed ERA5 wind stress, rotated such that positive wind stress is along the east coast of Greenland, toward the southwest. This demonstrates that the transport is significantly correlated with the upstream along-coast wind stress at all three lag times (Fig. 15, top row; positive correlation indicates wind stress leads WGCC signal). At time scales longer than this, the correlation is insignificant.
As noted above, both the cross-sectional area of the UPW and its velocity influence the transport variability. Therefore, we made analogous correlation maps for these two variables. The correlation between along-coast wind stress and the spatially averaged UPW velocity is strongest at 0 lag (Fig. 15, middle row), whereas the correlation of along-coast wind stress and UPW area is strongest at 1-2-month lags (Fig. 15, bottom row).

In an effort to explain this, we considered the coastal trapped wave model of Brink (2006). The model requires the cross-slope shape of the topography, the velocity structure, and the background stratification of the current in order to solve for the wave speeds. We used a simplified bathymetric profile, together with a surfaceintensified current and a background buoyancy frequency, all based on the mean mooring data. Additionally, the user can select whether the model solves for a rigid lid or free surface, for open or closed boundaries, and for a strong or weak value for bottom friction. We chose a free surface, with a closed boundary on the onshore side of the domain and open boundary on the offshore side of the domain. For bottom friction we used a value of $0.05 \mathrm{~cm} \mathrm{~s}^{-1}$ (weak friction). The solution for the coastal trapped barotropic wave speed is 


$$
c_{0}=\frac{f L\left(H-h_{s}\right)}{H}
$$

where $L$ is the shelf width $(35 \mathrm{~km}), f$ is the Coriolis parameter $\left(1.25 \times 10^{-4} \mathrm{~s}^{-1}\right), H$ is the basin depth $(1000 \mathrm{~m})$, and $h_{s}$ is the shelf depth $(200 \mathrm{~m})$ (Brink 1982). Based on these values, the barotropic wave speed is $3.5 \mathrm{~m} \mathrm{~s}^{-1}$. This is consistent with the short time lag between the wind stress and velocity of the UPW (Fig. 15, middle row). Specifically, the distance between $65^{\circ} \mathrm{N}$ along the East Greenland coast to the OSNAP WG mooring array is $1100 \mathrm{~km}$. This means that the barotropic wave, traveling at $3.5 \mathrm{~m} \mathrm{~s}^{-1}$, would propagate between these locations in 4 days. It implies that the sea surface height anomaly caused by the intensification of the winds along the east coast of Greenland travels at the barotropic coastal trapped wave speed to the OSNAP WG site, and the WGCC adjusts accordingly.

The area signal instead travels slower, taking 1-2 months to travel from the Denmark Strait region to the OSNAP WG array site (Fig. 15, bottom row). The Brink (1982) model is again used to compute the baroclinic wave speeds. The third mode has a phase speed of $c=22.6 \mathrm{~cm} \mathrm{~s}^{-1}$, which is consistent with the time scale of the calculated area signal propagation (56 days to travel the $1100 \mathrm{~km}$ at this phase speed). We note that Pickart et al. (2011) found a similar result regarding wave adjustment of the Beaufort Shelfbreak Jet due to remote wind forcing. In particular, the adjustment of the sea surface height occurred quickly, on the time scale of the barotropic mode, while the adjustment of the pycnocline took place on a slower time scale corresponding to the third baroclinic mode wave speed predicted by the Brink (1982) model. In our case the area of the UPW is dictated by the lateral displacement of the pycnocline associated with the WGCC, i.e., the movement of the $27.55 \mathrm{~kg} \mathrm{~m}^{-3}$ isopycnal, which corresponds to the seaward boundary of the wedge of UPW (Fig. 4). When the area is large, this isopycnal is displaced offshore, and when the area is small, this isopycnal is found closer to the shelfbreak. It should be noted that the arrival of the barotropic and baroclinic waves corresponds to the arrival of fronts, as derived in Allen (1976). The upstream, downwellingfavorable winds introduce a continual sea surface and isopycnal displacement to the water column due to the onshore Ekman transport, thus inhibiting the return to preforcing conditions on short time scales associated with waves of subinertial frequencies.

While these results explain the seasonality in transport of the UPW, it still remains to be determined what factors dictate the seasonal change in $T$ and $S$ documented in Fig. 14. Unlike the IW, the UPW is not advected around the perimeter of the Irminger Sea, but instead progresses along the shelf and shelfbreak of East Greenland from Fram Strait to Cape Farewell. Analogous to our calculation for the IW, we used the mooring data at the MA3 array to investigate ventilation of UPW, in this case using the onshore-most mooring in the EGCC. This revealed that the stratification of the water column is eroded and the mixed layer deepens over the course of the winter season, until it is sporadically homogenous from top to bottom by March. Hence, UPW is actively ventilated at MA3 during winter. Additionally, onshore Ekman transport along East Greenland should act to modify the UPW properties along its trajectory. Unfortunately, since neither MA4 nor the OSNAP WG array had moored CTD profilers, plus the data return of the tethered MicroCATs at $50 \mathrm{~m}$ was sparse at both arrays, it is not possible to document how much of the UPW was ventilated east and west of Cape Farewell. However, given that there is no evidence of an advective lag in UPW hydrographic properties between MA4 and the OSNAP WG array, it is likely that UPW continues to be directly ventilated in winter along its trajectory from the Irminger Sea into the eastern Labrador Sea. Further insights on this will require additional sensors on the inshore Cape Farewell OSNAP moorings.

\section{Summary and conclusions}

Using a high-resolution mooring array deployed between 2014 and 2018, we have characterized the structure, water mass composition, and seasonal variability of the West Greenland boundary current system. The boundary current system is comprised of three components, progressing from onshore to offshore: 1) the West Greenland Coastal Current (WGCC) advects cold and fresh UPW in the vicinity of the outer shelf and shelfbreak; 2) the West Greenland Current (WGC) transports warm and salty IW along the upper-slope (with some UPW in the surface layer); and 3) the DWBC advects overflow waters emanating from Denmark Strait (relatively cold and fresh DSOW) and the Faroe Bank Channel and Iceland-Faroe Ridge (relatively warm and salty NEADW). LSW is prevalent at the seaward side of the array within the offshore recirculation gyre, and also present in the WGC beneath the IW.

Based on the lateral distribution of LSW, together with guidance from previous work, we divided the flow into the boundary current portion versus the northward arm of the cyclonic recirculation gyre at the edge of the array. The total mean transport of the boundary current is $31.1 \pm 7.4 \mathrm{~Sv}$. Of the six water mass components, LSW contributed the largest transport, followed by NEADW, IW, and DSOW. The remaining two water masses, UPW and UAW, were associated with smaller, comparable transports. Using the historical definition of overflow 
water (denser than $27.8 \mathrm{~kg} \mathrm{~m}^{-3}$ ), we find that there is a loss of transport of this dense water as it rounds Cape Farewell, consistent with earlier studies. However, we demonstrated that some of the NEADW is lighter than $27.8 \mathrm{~kg} \mathrm{~m}^{-3}$, meaning that this definition does not account for all of the overflow water (plus entrainment) emanating from the Greenland-Scotland Ridge. Using our property definitions, we demonstrated that the true overflow component transports $2.2 \mathrm{~Sv}$ more than one would obtain using the historical density definition. We also determined that the transport of the entrained product deriving from the eastern overflow (NEADW) is comparable to that from the western overflow (DSOW).

While the total boundary current transport does not have a seasonal signal, the individual water mass components do vary seasonally in both transport and in their hydrographic properties. LSW transport reaches a maximum in spring, after strong wintertime convection during which the water becomes colder and fresher. This seasonality in transport is driven by fluctuations in the amount of LSW present, not by its velocity. Our results indicate that LSW penetrates the boundary current locally, through entrainment/mixing from the adjacent recirculation gyre, and also enters the current upstream in the Irminger Sea, where the newly ventilated water is subsequently advected around Cape Farewell.

In fall, the IW is warmest and saltiest, coincident with a maximum in transport. Using data from four different mooring arrays upstream of the OSNAP WG array, it was determined that IW is consistently modified through air-sea interaction during winter along the length of its trajectory around the Irminger Sea. This means that it is impossible to advectively track a seasonal signal of this water mass from site to site. Near Cape Farewell, however, the water mass subducts below cold and fresh UPW shed from the coastal current. As such, there is a clear advective lag in seasonal IW properties between the OSNAP WG array and the OSNAP mooring array northeast of Cape Farewell. The upstream wintertime ventilation cools, freshens, and densifies the IW, converting some of it to LSW. This conversion, together with the seasonal increase in LSW entering the current, results in an anticorrelation in transport between these two water masses.

The UPW in the WGCC also exhibits strong seasonality in its hydrographic properties, as well as its transport. The water is coldest, freshest, and its transport is maximum in the spring. The transport variability, which is dictated by both changes in cross-sectional area and speed of the UPW, is due to remote wind forcing. In particular, our analysis suggests that strong northerly winds off of East Greenland excite coastal trapped waves that propagate around Cape Farewell and adjust the
WGCC. The sea surface height anomaly travels at the barotropic wave speed which enhances the velocity, while the pycnocline anomaly travels at a slower baroclinic wave speed which increases the area of the UPW. The observed timing of these changes agrees with that predicted by a coastal trapped wave model. It was documented that, during winter, the UPW is ventilated throughout the water column on the outer East Greenland shelf at the upstream MA3 mooring site near Denmark Strait. Due to sparse instrument coverage, it was impossible to determine if such ventilation also occurs at the two OSNAP Cape Farewell arrays. However, the lack of an advective signal between the two sites implies that UPW continues to be directly ventilated during winter as it progresses from the Irminger Sea into the Labrador Sea.

This study has provided the first robust accounting of the boundary current of the eastern Labrador Sea, including its mean state and seasonally varying components. As the current system in this region is part of the North Atlantic meridional overturning circulation, its variability has important implications for climate. Future work will compare the boundary currents on the two sides of the Labrador Sea using the OSNAP mooring data on the Labrador shelf/slope. It is also of interest to investigate further the role of the boundary current system in influencing the conditions in the interior Labrador Sea, including its role in modulating wintertime convection and in the subsequent restratification that takes place in spring and summer. Toward this end, future efforts will focus on the mesoscale processes in the current that help dictate shelf-basin exchange.

Acknowledgments. The authors are thankful to Captain Kent Sheasley, Captain Derek Bergeron, and the entire crew of the R/V Knorr and R/V Neil Armstrong, for their efforts in making the OSNAP deployment and recovery cruises successful. We thank John Kemp, Jim Ryder, Brian Hogue, Andrew Davies, and Rick Trask for the design, fabrication, preparation of instruments, and deployment of the moorings. Leah McRaven and Carolina Nobre oversaw the shipboard CTD operations. A.P., R.S.P., F.B., D.J.T., and A.L.R. were funded by Grants OCE-1259618 and OCE-1756361 from the National Science Foundation. I.L.B, F.S., and J.H. were supported by U.S. National Science Foundation Grants OCE-1258823 and OCE1756272. Mooring data from MA2 was funded by the European Union 7th Framework Programme (FP7 2007-2013) under Grant 308299 (NACLIM) and the Horizon 2020 research and innovation program under Grant 727852 (Blue-Action). J.K. and M.O. acknowledge EU Horizon 2020 funding Grants 727852 
(Blue-action) and 862626 (EuroSea) and from the German Ministry of Research and Education (RACE Program). G.W.K.M. acknowledges funding from the Natural Sciences and Engineering Research Council.

Data availability statement. The OSNAP mooring data are publicly available at o-snap.org through the Duke Digital Repository. The calibrated and qualitycontrolled data are provided by each participating institution. U.S. Labrador Sea eastern boundary array, doi: 10.7924/r4fj2dr7k, U.S. east Cape Farewell slope array, doi:10.7924/r4fb50z9b, NIOZ western Mid-Atlantic-Ridge array, doi:10.4121/uuid:77b2c4fc-c253-4494-91bd-8d1ef66a014a, doi:10.4121/uuid:9ae97ceb-39e4-43ec-abdb-614103285c16; U.S. eastern Mid-Atlantic-Ridge array, doi:10.7924/ r42n52w51. Mooring data from MA3 can be found at http://kogur.whoi.edu/php.

\section{REFERENCES}

Allen, J. S., 1976: Some aspects of the forced wave response of stratified coastal regions. J. Phys. Oceanogr., 6, 113-119, https://doi.org/ 10.1175/1520-0485(1976)006<0113:SAOTFW >2.0.CO;2.

Bacon, S., G. Reverdin, I. G. Rigor, and H. M. Snaith, 2002: A freshwater jet on the east Greenland shelf. J. Geophys. Res., 107, 3068, https://doi.org/10.1029/2001JC000935.

Beaird, N. L., P. B. Rhines, and C. C. Eriksen, 2013: Overflow waters at the Iceland-Faroe Ridge observed in multiyear Seaglider surveys. J. Phys. Oceanogr., 43, 2334-2351, https:// doi.org/10.1175/JPO-D-13-029.1.

Bower, A. S., M. S. Lozier, S. F. Gary, and C. W. Boning, 2009: Interior pathways of the North Atlantic meridional overturning circulation. Nature, 459, 243-247, https://doi.org/10.1038/nature07979.

Brambilla, E., L. D. Talley, and P. E. Robbins, 2008: Subpolar mode water in the northeastern Atlantic: 2. Origin and transformation. J. Geophys. Res., 113, C04026, https://doi.org/ 10.1029/2006JC004063.

Brearley, J. A., R. S. Pickart, H. Valdimarsson, S. Jonsson, R. W. Schmitt, and T. W. N. Haine, 2012: The east Greenland boundary current system south of Denmark Strait. Deep-Sea Res. I, 63, 1-19, https://doi.org/10.1016/j.dsr.2012.01.001.

Brink, K. H., 1982: A comparison of long coastal-trapped wave theory with observations off Peru. J. Phys. Oceanogr., 12, 897-913, https://doi.org/10.1175/1520-0485(1982)012<0897: ACOLCT $>2.0 . \mathrm{CO} ; 2$.

— , 2006: Coastal-trapped waves with finite bottom friction. Dyn. Atmos. Oceans, 41, 172-190, https://doi.org/10.1016/ j.dynatmoce.2006.05.001.

Buch, E., S. A. Pedersen, and M. H. Ribergaard, 2004: Ecosystem variability in west Greenland waters. J. Northwest Atl. Fish. Sci., 34, 13-28, https://doi.org/10.2960/J.v34.m479.

Clarke, A., and J. C. Gascard, 1983: The formation of Labrador Sea water. Part I: Large-scale processes. J. Phys. Oceanogr., 13, 1764-1778, https://doi.org/10.1175/1520-0485(1983)013<1764: TFOLSW $>2.0 . \mathrm{CO} ; 2$.

Cuny, J., P. B. Rhines, P. P. Niiler, and S. Bacon, 2002: Labrador Sea boundary currents and the fate of the Irminger Sea water. J. Phys. Oceanogr., 32, 627-647, https://doi.org/10.1175/ 1520-0485(2002)032<0627:LSBCAT >2.0.CO;2.
- - - and R. Kwok, 2005: Davis Strait volume, freshwater and heat fluxes. Deep-Sea Res. I, 52, 519-542, https://doi.org/ 10.1016/j.dsr.2004.10.006.

Curry, B., C. M. Lee, and B. Petrie, 2011: Volume, freshwater, and heat fluxes through Davis Strait, 2004-05. J. Phys. Oceanogr., 41, 429-436, https://doi.org/10.1175/2010JPO4536.1.

,,,--- R. E. Moritz, and R. Kwok, 2014: Multiyear volume, liquid freshwater, and sea ice transports through Davis Strait, 2004-10. J. Phys. Oceanogr., 44, 1244-1266, https://doi.org/10.1175/JPO-D-13-0177.1.

Daniault, N., P. Lherminier, and H. Mercier, 2011: Circulation and transport at the southeast tip of Greenland. J. Phys. Oceanogr., 41, 437-457, https://doi.org/10.1175/2010JPO4428.1.

de Jong, M. F., A. S. Bower, and H. H. Furey, 2014: Two years of observations of warm-core anticyclones in the Labrador Sea and their seasonal cycle in heat and salt stratification. J. Phys. Oceanogr., 44, 427-444, https://doi.org/10.1175/JPO-D-13-070.1.

Dickson, R. R., and J. Brown, 1994: The production of North Atlantic deep water: Sources, rates, and pathways. J. Geophys. Res., 99, 12 319-12 341, https://doi.org/10.1029/94JC00530.

Fischer, J., M. Visbeck, R. Zantopp, and N. Nunes, 2010: Interannual to decadal variability of outflow from the Labrador Sea. Geophys. Res. Lett., 37, L24510, https://doi.org/10.1029/2010GL045321.

Fratantoni, P. S., and R. S. Pickart, 2007: The western North Atlantic shelfbreak current system in summer. J. Phys. Oceanogr., 37, 2509-2533, https://doi.org/10.1175/JPO3123.1.

Gelderloos, R., C. A. Katsman, and A. S. S. Drijfhout, 2011: Assessing the roles of three eddy types in restratifying the Labrador Sea after deep convection. J. Phys. Oceanogr., 41, 2102-2119, https://doi.org/10.1175/JPO-D-11-054.1.

Grist, J. P., and Coauthors, 2014: Seasonal variability of the warm Atlantic water layer in the vicinity of the Greenland shelf break. Geophys. Res. Lett., 41, 8530-8537, https://doi.org/ 10.1002/2014GL062051.

Hall, M. M., D. J. Torres, and I. Yashayaev, 2013: Absolute velocity along the AR7W section in the Labrador Sea. Deep-Sea Res. I, 72, 72-87, https://doi.org/10.1016/j.dsr.2012.11.005.

Harden, B. E., R. S. Pickart, and I. A. Renfrew, 2014a: Offshore transport of dense water from the East Greenland shelf. J. Phys. Oceanogr., 44, 229-245, https://doi.org/10.1175/ JPO-D-12-0218.1.

— , F. Straneo, and D. A. Sutherland, 2014b: Moored observations of synoptic and seasonal variability in the East Greenland coastal current. J. Geophys. Res. Oceans, 119, 8838-8857, https://doi.org/10.1002/2014JC010134.

, and Coauthors, 2016: Upstream sources of the Denmark Strait overflow: Observations from a high-resolution mooring array. Deep-Sea Res. I, 112, 94-112, https://doi.org/10.1016/ j.dsr.2016.02.007.

Herbach, H., and D. Dee, 2016: ERA5 reanalysis is in production. ECMWF Newsletter, No. 147, ECMWF, Reading, United Kingdom, 7, http://www.ecmwf.int/sites/default/files/elibrary/ 2016/16299-newsletter-no147-spring-2016.pdf.

Holliday, N. P., A. Meyer, S. Bacon, S. Alderson, and B. A. de Cuevas, 2007: The retroflection of part of the east Greenland current at Cape Farewell. Geophys. Res. Lett., 34, L07609, https://doi.org/10.1029/2006GL029085.

, S. Bacon, J. Allen, and E. L. McDonagh, 2009: Circulation and transport in the western boundary currents at Cape Farewell, Greenland. J. Phys. Oceanogr., 39, 1854-1870, https://doi.org/10.1175/2009JPO4160.1.

Hopkins, J. E., N. P. Holliday, D. Rayner, L. Houpert, I. Le Bras, F. Straneo, C. Wilson, and S. Bacon, 2019: Transport 
variability of the Irminger Sea deep western boundary current from a mooring array. J. Geophys. Res. Oceans, 124, 3246-3278, https://doi.org/10.1029/2018JC014730.

Hurrell, J. W., 1995: Decadal trends in the North Atlantic oscillation: Regional temperatures and precipitation. Science, 269, 676679, https://doi.org/10.1126/science.269.5224.676.

Kanzow, T., U. Send, W. Zenk, A. D. Chave, and M. Rhein, 2006: Monitoring the integrated deep meridional flow in the tropical North Atlantic: Long-term performance of a geostrophic array. Deep-Sea Res. I, 53, 528-546, https://doi.org/10.1016/ j.dsr.2005.12.007.

Khatiwala, S., and Coauthors, 2013: Global ocean storage of anthropogenic carbon. Biogeosciences, 10, 2169-2191, https:// doi.org/10.5194/bg-10-2169-2013.

Killworth, P. D., 1983: Deep convection in the world ocean. Rev. Geophys. Space Phys., 21, 1-26, https://doi.org/10.1029/RG021i001p00001.

Krauss, W., 1995: Currents and mixing in the Irminger Sea and in the Iceland basin. J. Geophys. Res., 100, 10 851-10 871, https:// doi.org/10.1029/95JC00423.

Lab Sea Group, 1998: The Labrador Sea deep convection experiment. Bull. Amer. Meteor. Soc., 79, 2033-2058, https://doi.org/ 10.1175/1520-0477(1998)079<2033:TLSDCE > 2.0.CO;2.

Lavender, K. L., R. E. Davis, and W. B. Owens, 2000: Mid-depth recirculation observed in the interior Labrador and Irminger Seas by direct velocity measurements. Nature, 407, 66-69, https://doi.org/10.1038/35024048.

,-- , and,- 2002 : Observations of open-ocean deep convection in the Labrador Sea from subsurface floats. J. Phys. Oceanogr., 32, 511-526, https://doi.org/10.1175/1520-0485(2002) 032<0511:OOOODC $>2.0 . \mathrm{CO} ; 2$.

Lazier, J., R. Hendry, A. Clarke, I. Yashayaev, and P. Rhines, 2002: Convection and restratification in the Labrador Sea, 1990-2000. Deep-Sea Res. I, 49, 1819-1835, https://doi.org/ 10.1016/S0967-0637(02)00064-X.

Le Bras, I. A. A., I. Yashayaev, and J. M. Toole, 2017: Tracking Labrador Sea water property signals along the deep western boundary current. J. Geophys. Res. Oceans, 122, 5348-5366, https://doi.org/10.1002/2017JC012921.

— , F. Straneo, J. Holte, and N. P. Holliday, 2018: Seasonality of freshwater in the east Greenland current system from 2014 to 2016. J. Geophys. Res. Oceans, 123, 8828-8848, https://doi.org/ 10.1029/2018JC014511.

,,,--- M. F. de Jong, and N. P. Holliday, 2020: Rapid export of waters formed by convection near the Irminger Sea's western boundary. Geophys. Res. Lett., 47, e2019GL085989, https://doi.org/10.1029/2019GL085989.

Lilly, J. M., P. B. Rhines, M. Visbeck, R. E. Davis, J. R. N. Lazier, F. Schott, and D. Farmer, 1999: Observing deep convection in the Labrador Sea during winter 1994/95. J. Phys. Oceanogr., 29, 2065-2098, https://doi.org/10.1175/ 1520-0485(1999)029<2065:ODCITL>2.0.CO;2.

,-- - F. Schott, K. Lavender, J. R. N. Lazier, U. Send, and E. A. D'Asaro, 2003: Observations of the Labrador Sea eddy field. Prog. Oceanogr., 59, 75-176, https://doi.org/10.1016/ j.pocean.2003.08.013.

Lin, P., R. S. Pickart, D. J. Torres, and A. Pacini, 2018: Evolution of the freshwater coastal current at the southern tip of Greenland. J. Phys. Oceanogr., 48, 2127-2140, https:// doi.org/10.1175/JPO-D-18-0035.1.

Lozier, M. S., and Coauthors, 2017: Overturning in the subpolar North Atlantic program: A new international ocean observing system. Bull. Amer. Meteor. Soc., 98, 737-752, https://doi.org/ 10.1175/BAMS-D-16-0057.1.
- and Coauthors, 2019: A sea change in our view of overturning in the subpolar North Atlantic. Science, 363, 516-521, https:// doi.org/10.1126/science.aau6592.

Luo, H., R. M. Castelao, A. K. Rennermalm, M. Tedesco, A. Bracco, P. L. Yager, and T. L. Mote, 2016: Oceanic transport of surface meltwater from the southern Greenland ice sheet. Nat. Geosci., 9, 528-532, https://doi.org/10.1038/ngeo2708.

Martin, R., and G. W. K. Moore, 2007: Air-sea interaction associated with a Greenland reverse tip jet. Geophys. Res. Lett., 34, L24802, https://doi.org/10.1029/2007GL031093.

McCartney, M. S., 1992: Recirculating components to the deep boundary current of the northern North Atlantic. Prog. Oceanogr., 29, 283-383, https://doi.org/10.1016/0079-6611(92) 90006-L.

_ , and L. D. Talley, 1982: The subpolar mode water of the North Atlantic Ocean. J. Phys. Oceanogr., 12, 1169-1188, https://doi.org/ 10.1175/1520-0485(1982)012<1169:TSMWOT>2.0.CO;2.

_—, and —_, 1984: Warm water to cold water conversion in the northern North Atlantic Ocean. J. Phys. Oceanogr., 14, 922-935, https://doi.org/10.1175/1520-0485(1984)014<0922: WTCWCI $>2.0 . \mathrm{CO} ; 2$.

Moore, G. W. K., and I. A. Renfrew, 2005: Tip jets and barrier winds: A QuikSCAT climatology of high wind speed events around Greenland. J. Climate, 18, 3713-3725, https://doi.org/ 10.1175/JCLI3455.1.

Myers, P. G., N. Kulan, and M. H. Ribergaard, 2007: Irminger water variability in the west Greenland current. Geophys. Res. Lett., 34, L17601, https://doi.org/10.1029/2007GL030419.

— C. Donnelly, and M. Ribergaard, 2009: Structure and variability of the west Greenland Current in summer derived from 6 repeat standard sections. Prog. Oceanogr., 80, 93-112, https://doi.org/10.1016/j.pocean.2008.12.003.

NGDC, 2006: ETOPO2v2 Global gridded 2-minute database. http://www.ngdc.noaa.gov/mgg/global/etopo2.html.

Ohigashi, T., and G. W. K. Moore, 2009: Fine structure of a Greenland reverse tip jet: A numerical simulation. Tellus, 61A, 512-526, https://doi.org/10.1111/j.1600-0870.2009.00399.x.

Pawlowicz, R., B. Beardsley, and S. Lentz, 2002: Classical tidal harmonic analysis including error estimates in MATLAB using T-TIDE. Comput. Geosci., 28, 929-937, https://doi.org/ 10.1016/S0098-3004(02)00013-4.

Pickart, R. S., 1992: Mid-depth ventilation in the western boundary current system of the sub-polar gyre. Deep-Sea Res. I, 39, 1553-1572, https://doi.org/10.1016/0198-0149(92)90047-w.

_ the North Atlantic meridional overturning circulation. J. Phys. Oceanogr., 37, 2207-2227, https://doi.org/10.1175/JPO3178.1.

— W. M. Smethie, J. R. N. Lazier, E. P. Jones, and W. J. Jenkins, 1996: Eddies of newly formed upper Labrador Sea water. J. Geophys. Res., 101, 20 711-20 726, https://doi.org/10.1029/ 96JC01453.

_ M. A. Spall, and J. R. N. Lazier, 1997: Mid-depth ventilation in the western boundary current system of the sub-polar gyre. Deep-Sea Res. I, 44, 1025-1054, https://doi.org/10.1016/S09670637(96)00122-7.

—_, D. J. Torres, and R. A. Clarke, 2002: Hydrography of the Labrador Sea during active convection. J. Phys. Oceanogr., 32, 428-457, https://doi.org/10.1175/1520-0485(2002)032<0428: HOTLSD $>2.0$. CO;2.

, M. A. Spall, M. H. Ribergaard, G. W. K. Moore, and R. F. Milliff, 2003a: Deep convection in the Irminger Sea forced by the Greenland tip jet. Nature, 424, 152-156, https:// doi.org/10.1038/nature01729. 
—, F. Straneo, and G. W. K. Moore, 2003b: Is Labrador Sea water formed in the Irminger basin? Deep-Sea Res. I, 50, 23-52, https://doi.org/10.1016/S0967-0637(02)00134-6.

— D. J. Torres, and P. S. Fratantoni, 2005: The east Greenland spill jet. J. Phys. Oceanogr., 35, 1037-1053, https://doi.org/ 10.1175/JPO2734.1.

—_, M. A. Spall, G. W. K. Moore, T. J. Weingartner, R. A. Woodgate, K. Aagaard, and K. Shimada, 2011: Upwelling in the Alaskan Beaufort Sea: Atmospheric forcing and local versus non-local response. Prog. Oceanogr., 88, 78-100, https://doi.org/10.1016/j.pocean.2010.11.005.

Prater, M. D., 2002: Eddies in the Labrador Sea as observed by profiling RAFOS floats and remote sensing. J. Phys. Oceanogr., 32, 411-427, https://doi.org/10.1175/1520-0485(2002)032<0411 EITLSA $>2.0 . \mathrm{CO} ; 2$

Renfrew, I. A., G. W. K. Moore, P. S. Guest, and K. Bumke, 2002: A comparison of surface layer and surface turbulent flux observations over the Labrador Sea with ECMWF analyses and NCEP reanalyses. J. Phys. Oceanogr., 32, 383-400, https://doi.org/10.1175/1520-0485(2002)032<0383:ACOSLA > 2.0.CO;2.

- , G. N. Peterson, D. A. J. Sproson, G. W. K. Moore, H. Adiwidjaja, S. Zhang, and R. North, 2009: A comparison of aircraft-based surface-layer observations over Denmark Strait and the Irminger Sea with meteorological analyses and QuikSCAT winds. Quart. J. Roy. Meteor. Soc., 135, 2046-2066, https://doi.org/10.1002/qj.444.

Rhein, M., L. Stramma, and U. Send, 1995: The Atlantic deep western boundary current: Water masses and transports near the equator. J. Geophys. Res., 100, 2441-2457, https://doi.org/ 10.1029/94JC02355.

Ribergaard, M. H., 2013: Oceanographic investigations off West Greenland 2012. Danish Meteorological Institute, 50 pp., http://ocean.dmi.dk/staff/mhri/Docs/scr13-003.pdf.

Rudels, B., E. Fahrbach, J. Meincke, G. Budéus, and P. Ericksson, 2002: The East Greenland current and its contribution to the Denmark Strait Overflow. ICES J. Mar. Sci., 59, 1133-1154, https://doi.org/10.1006/jmsc.2002.1284.

Rykova, T., F. Straneo, J. M. Lilly, and I. Yashayaev, 2009: Irminger current anticyclones in the Labrador Sea observed in the hydrographic record, 1990-2004. J. Mar. Res., 67, 361-384, https://doi.org/10.1357/002224009789954739.

and A. S. Bower, 2015: Seasonal and interannual variability of the west Greenland current system in the Labrador Sea in 1993-2008. J. Geophys. Res. Oceans, 120, 1318-1332, https://doi.org/10.1002/2014JC010386.

Schulze Chretien, L. M., and E. Frajka-Williams, 2018: Winddriven transport of fresh shelf water into the upper $30 \mathrm{~m}$ of the
Labrador Sea. Ocean Sci., 14, 1247-1264, https://doi.org/ 10.5194/os-14-1247-2018.

Smith, W. H. F., and P. Wessel, 1990: Gridding with continuous curvature splines in tension. Geophysics, 55, 293-305, https:// doi.org/10.1190/1.1442837.

Straneo, F., 2006: Heat and freshwater transport through the central Labrador Sea. J. Phys. Oceanogr., 36, 606-628, https:// doi.org/10.1175/JPO2875.1.

Sutherland, D. A., and R. S. Pickart, 2008: The east Greenland coastal current: Structure, variability, and forcing. Prog. Oceanogr., 78, 58-77, https://doi.org/10.1016/j.pocean.2007.09.006.

, _ - E. P. Jones, K. Azetsu-Scott, A. J. Eert, and J. Ólafsson, 2009: Freshwater composition of the waters off southeast Greenland and their link to the Arctic Ocean. J. Geophys. Res., 114, C05020, https://doi.org/10.1029/2008JC004808.

Takahashi, T., and Coauthors, 2009: Climatological mean and decadal change in surface ocean $\mathrm{pCO}_{2}$, and net sea-air $\mathrm{CO}_{2}$ flux over the global oceans. Deep-Sea Res. II, 56, 554-577, https:// doi.org/10.1016/j.dsr2.2008.12.009.

Tanhua, T., K. Bulsiewicz, and M. Rhein, 2005: Spreading of overflow water from the Greenland to the Labrador Sea. Geophys. Res. Lett., 32, L10605, https://doi.org/10.1029/2005GL022700.

Våge, K., R. S. Pickart, G. W. K. Moore, and M. H. Ribergaard, 2008: Winter mixed-layer development in the central Irminger Sea: The effect of strong, intermittent wind events. J. Phys. Oceanogr., 38, 541-565, https://doi.org/10.1175/2007JPO3678.1.

vection to the subpolar North Atlantic Ocean in winter 2007-2008. Nat. Geosci., 2, 67-72, https://doi.org/10.1038/ ngeo382.

— tion, and interannual variability. Deep-Sea Res. I, 58, 590-614, https://doi.org/10.1016/j.dsr.2011.03.001.

von Appen, W.-J., R. S. Pickart, K. H. Brink, and T. W. N. Haine, 2014a: Water column structure and statistics of Denmark Strait Overflow Water cyclones. Deep-Sea Res. I, 84, 110-126, https://doi.org/10.1016/j.dsr.2013.10.007.

— , and Coauthors, 2014b: The East Greenland Spill Jet as an important component of the Atlantic meridional overturning circulation. Deep-Sea Res. I, 92, 75-84, https://doi.org/10.1016/ j.dsr.2014.06.002.

Yashayaev, I., and A. Clarke, 2008: Evolution of North Atlantic water masses inferred from Labrador Sea salinity series. Oceanography, 21, 30-45, https://doi.org/10.5670/oceanog.2008.65.

, and R. R. Dickson, 2008: Transformation and fate of overflows in the northern North Atlantic. Arctic-Subarctic Ocean Fluxes, R. R. Dickson, J. Meincke, and P. Rhines, Eds., Springer, 505-526. 